\title{
EVALUATION OF BIOACTIVE COMPOUNDS IN CEREALS STUDY OF WHEAT, BARLEY, OAT AND SELECTED GRAIN PRODUCTS
}

\author{
Małgorzata Nogala-Kałucka ${ }^{1}$, Alicja Kawka², Krzysztof Dwiecki ${ }^{1}$, Aleksander Siger ${ }^{1 凶}$ \\ ${ }^{1}$ Department of Food Biochemistry and Analysis, Poznań University of Life Sciences \\ Mazowiecka 48, 60-623 Poznań, Poland \\ ${ }^{2}$ Institute of Food Technology, Poznań University of Life Sciences \\ Wojska Polskiego 28, 60-637 Poznań, Poland
}

\begin{abstract}
Background. One of the requirements for proper nutrition and maintenance of good health is to supply the body, through diet, with an appropriately increased quantity of bioactive compounds. With this in mind, modern milling and baking industries keep introducing new types of products. The use of such additives as wholegrain flours and bran in baked products provided the basis for research in this paper.

Materials and methods. The aim of the study was to conduct a qualitative and quantitative evaluation of marketable wheat, barley and oat grain, used as raw materials to produce dehulled kernels, ground grain, wholemeal flour and wheat flour type 550 (all-purpose or plain flour), as well as wheat bran. Additionally, analyses were performed to determine the chemical composition and contents of nutrients, selected bioactive compounds and antioxidant activity.

Results. The studied raw materials in commercial cereal differ in their chemical composition. Dehulling of wheat, barley and oat grains significantly contributed to the reduction of minerals, protein and total dietary fiber (TDF) contents, except for the amount of protein in dehulled wheat and oat grains. Oat bran, in contrast to other oat products, was characterized by the highest contents of minerals, protein, TDF, and the smallest amounts of saccharides and total starch. The lowest content of minerals was recorded in wheat flour type 550. Thermal processes affect the concentration of tocochromanols in the grain, with tocotrienols being more resistant to hydrothermal treatment than tocopherols. Grain dehulling also significantly decreased the total amount of tocochromanols in relation to the original grains.

Conclusion. Wheat products differ in the contents of their individual components. They are characterized by high contents of tocochromanols, phenolic compounds and water-extractable arabinoxylans, with the exception of white refined wheat flour, which is mainly a source of saccharides. In the case of barley and oat products, the analysis showed no differences between these product groups. It was also shown that dehulling of barley and oat grain causes statistically significant differences in the contents of nutrients and natural antioxidants.
\end{abstract}

Keywords: wheat, barley, oat, tocochromanols, DPPH*, antioxidant activity, phenolic compounds

This study was financially supported by the National Centre of Science, Poland (Project No. N N312 505340).

\aleksander.siger@up.poznan.pl, https://orcid.org/0000-0002-3681-153X, phone +48618487365 


\section{INTRODUCTION}

According to recommendations by the Pyramid of Healthy Nutrition and Physical Activity (Gil et al., 2014), grains and grain-based products are most frequently recommended and consumed immediately after fruit and vegetables. They not only enrich food with indispensable, energy providing nutrients, but also with vitamins, minerals, fiber and native antioxidants, as well as other health promoting substances (Ragaee et al., 2012). The bioactive compounds found in grains comprise a wide range of hydrophilic and lipophilic natural antioxidants. In Europe, in countries such as Germany, Poland and the Baltic countries, the everyday diet is based on grains and consumption of cereal products is particularly high (Lachman et al., 2012; Landberg et al., 2014). Bioactive compounds contained in grains were already studied in the 1970's and 1980 's, but to date their role has not been fully defined (Lachman et al., 2012; Masisi et al., 2016; Ragaee et al., 2012). Wheat, rye, oats and barley are the most popular grains of bread and non-bread quality. Wheat and rye flours are used for baking, while those made from oats and barley mainly for making grits and breakfast cereals (Gawęcki and Obuchowski, 2016). Attempts are being made to introduce barley and oat wholegrain flours as well as bran into baked products because of the valuable bioactive compounds contained within them. Increasingly often, dieticians and doctors are advocating intake of nutrients abundant in cereal products present in our diet. Their versatile health promoting influence on the human organism cannot be underrated. The most important aspect is related to the contribution of nutrients to the prevention of cardiovascular diseases, nervous system diseases, cancer and type- 2 diabetes. The antioxidant action of lipophilic and hydrophilic substances is of crucial importance here. These compounds participate in the free radical deactivation reactions occurring during metabolic processes, contributing to the maintenance of the natural balance between physiological oxidation, which is the basis of all life and antioxidant processes (Belobrajdic and Bird, 2013a; Frank et al., 2012).

Tocochromanols and phenolic acids are considered particularly important bioactive compounds found in grains (Heleno et al., 2015; Ndolo and Beta, 2014; Piironen et al., 1986; Rice-Evans et al., 1997; Zieliński et al., 2007). The last twenty years of the 20th century marked the beginning of research which has continued to this date and regarding the properties of these substances and their impact not only on grains, but also on consumed cereal products and thus their influence on consumers' health (Gani et al., 2012). They are small molecule compounds found mainly in free form; they enter into no physical or chemical interactions with biological matrix macromolecules (Schneider, 2005; Žilić et al., 2011). Tocochromanols present in grains are the most valuable as far as their in vivo and in vitro activity is concerned (Masisi et al., 2016). In general, they are defined as vitamin E-active compounds and the broad spectrum of their activity in living organisms has been constantly supplemented with new data (Frank et al., 2012). Numerous studies have proved that small quantities of tocotrienols in vivo display more favourable biological properties than tocopherols (Idehen et al., 2017).

The activity of phenolic acids depends upon their structure and the number of hydroxyl groups in their molecules, as well as the degree of their esterification. Therefore, throughout the botanical kingdom they are found mainly in bound form as esters and glycosides (Heleno et al., 2015; Idehen et al., 2017; Masisi et al., 2016). Some phenolic acids, such as caffeic, chlorogenic or ferulic, display an ability to block cancerogenic compounds generated during metabolic changes of cancerogenic substances such as e.g. 4-nitroquinoline-1-oxides (Lamer-Zarawska and Oszmiański, 1998). They inhibit the activity of enzymes belonging to the group of oxidases, while they are also capable of inhibiting cancer development. In addition, they display different pharmacologic effects upon the human organisms thanks to their antibacterial, antiseptic, haemostatic and cholagogic properties.

The human body is equipped with a system for preventing free radical action thanks to the presence of endogenous substances with antioxidant properties. However, this system gets weaker with age (Lobo et al., 2010). For this reason, one of the requirements for proper nutrition and maintenance of good health is to supply the body, through diet, with an appropriately increased quantity of bioactive compounds. With this in mind, modern milling and baking industries keep introducing new types of products (Kawka et al., 2014; Kawka and Achremowicz, 2014). The use of 
Nogala-Kałucka, M., Kawka, A., Dwiecki, K., Siger, A. (2020). Evaluation of bioactive compounds in cereals. Study of wheat, barley, oat and selected grain products. Acta Sci. Pol. Technol. Aliment., 19(4), 405-423. http://dx.doi.org/10.17306/J.AFS.2020.0858

such additives as wholegrain flours and bran in baked products provided the basis for research in this paper. The aim was to investigate the chemical composition as well as the contents of lipophilic and hydrophilic antioxidants in selected grains and products obtained after their technological processing, including the antioxidant activity resulting from their presence.

\section{MATERIALS AND METHODS}

\section{Materials}

The materials for analyses consisted of commercial raw materials such as hulled and dehulled wheat grain denoted as A1 and A2, analogous samples of barley: $\mathrm{B} 1$ and $\mathrm{B} 2$, oats: $\mathrm{C} 1$ and $\mathrm{C} 2$, along with their processed products. Through mechanical processing of dehulled grain (A2, B2, C2) the following wheat products were obtained: ground grain $\mathrm{A} 3$, wholemeal flour $\mathrm{A} 4$, wheat flour type $550 \mathrm{~A} 5$, as well as barley products: ground grain $\mathrm{B} 3$, wholemeal flour $\mathrm{B}$, and oat products: broken grain $\mathrm{C} 3$, wholemeal flour $\mathrm{C} 4$ and oat bran $\mathrm{C} 5$. The raw materials were sampled at random directly at the production line of Zakłady Przetwórstwa Zbożowo-Młynarskiego Sp. z o.o. in Kruszwica in three replications and next combined by mixing to produce bulk samples. From such a prepared bulk sample, smaller batches of approx. $5 \mathrm{~kg}$ were weighed, which in turn constituted the initial material for specific assays. The samples were stored in containers at $t= \pm 5^{\circ} \mathrm{C}$.

\section{Quality characteristics of wheat, barley and oat grain}

The moisture content was determined by the oven dry method at a temperature of $130^{\circ} \mathrm{C}$ according to ICC no. 110/1 (1976). The bulk density of grain was determined according to PN-EN ISO 7971-3 (2019). In turn, the 1000 kernel weight was determined according to PN EN ISO 520 (2011). The contents of impurities, including hazardous contaminants, were assayed following ICC no. 103/1 (1972). The Hagberg falling number was recorded using a type 1400 Falling Number apparatus according to ICC no. 107/1 (1995).

\section{Determination of mineral (ash) content}

The ash content was determined in three simultaneous replications according to ICC no. 104/1 (1990).

\section{Determination of crude protein content}

The crude protein content was determined in three simultaneous replications according to Kjeldahl using a Kjeltec System 1026 apparatus by Foss-Tecator following ICC no. 105/2 (1994). When converting nitrogen content to protein, a conversion factor of 5.7 was applied in the case of wheat, while 6.25 was applied for barley and oat.

\section{Extraction and measurement of total lipids}

The total lipid content in seeds is typically measured by Soxhlet extraction. Gravimetric determination of total lipid contents consisted of multiple continuous sample extraction with $n$-hexane (for 4 hours). Extraction was performed using an automatic Soxhlet Büchi Extraction System B-811 (Büchi Labortechnik AG, Flawil, Switzerland).

\section{Determination of total dietary fiber (TDF) and its soluble (SDF) and insoluble fractions (IDF)} The contents of SDF and IDF were determined gravimetrically in three simultaneous replications according to Asp et al. (1983) using a Fibertec System E apparatus by FOSS. The TDF content was calculated by adding up SDF and IDF contents. In turn, the total carbohydrate content in the samples was calculated from the difference in total dry matter content and the total contents of ash, protein, lipids and total dietary fiber (TDF).

\section{Determination of total starch (TS)}

The total starch content was determined using a Total Starch Assay Kit by Megazyme according to the modified method (AACC method 76-13.01, n.d.). The TS content was assayed in 4 simultaneous replications and recorded, converted to glucose found in the starch chain and expressed in percentage of sample dry matter.

\section{Determination of total $\beta$-glucans ( $\beta$-GLU)}

The total $\beta$-GLU content was determined using a Mixed Linkage $\beta$-Glucan Assay Kit by Megazyme (Henry, 1985; ICC no. 166, 1998). The total $\beta$-GLU content was assayed in 4 simultaneous replications, converted to glucose found in the $\beta$-GLU chain and expressed in percentage of sample dry matter. 


\section{Determination of total arabinoxylans (AX), water-extractable arabinoxylans (WE-AX) and water unextractable arabinoxylans (WU-AX)}

The contents of total AX and WE-AX were determined by colorimetry according to Hashimoto et al. (1987). The contents of total AX and WE-AX were assayed in 3 simultaneous replications, converted to xylose in the AX chain and expressed in percentage sample dry matter. In turn, the WU-AX content was calculated from the difference between total AX and WE-AX contents.

\section{Tocochromanol contents}

In order to determine the tocopherol content, the grain samples ( $2 \mathrm{~g}$ ) were saponified using $60 \% \mathrm{KOH}(2 \mathrm{ml})$, ethanol $(20 \mathrm{ml})$ and pyrogallol $(0.5 \mathrm{~g})$. Saponification was run at the ethanol boiling point temperature for $30 \mathrm{~min}$. After saponification, the unsaponifiable substances were extracted using $50 \mathrm{ml} n$-hexane/ethyl acetate $(90: 10 \mathrm{v} / \mathrm{v})$. Tocopherols and tocotrienols were qualitatively and quantitatively identified using liquid chromatography HPLC (Waters 600 Asc. Milford, MA, USA). A LiChrosorb Si60 column $(250 \times$ $4.6 \mathrm{~mm} ; 5 \mu \mathrm{m})$ and a LiChrospher Si60 precolumn were used (Merck, Germany). The mobile phase consisted of $n$-hexane and 1,4-dioxane $(97: 4 \mathrm{v} / \mathrm{v})$ at a flow rate of $1.0 \mathrm{ml} / \mathrm{min}$. The fluorometric detector (Waters 474 Asc. Milford, MA, USA) worked at excitation $(\lambda=295 \mathrm{~nm})$ and emission $(\lambda=330 \mathrm{~nm})$ for tocochromanols and PC-8 (Ryynänen et al., 2004).

\section{Methanol extracts of phenolic compounds}

All samples were defatted using an automatic Soxhlet Büchi Extraction System B-811 (Büchi Labortechnik AG, Flawil, Switzerland). Extraction with $n$-hexane was run for two hours. To obtain this, each sample was extracted three times with $80 \%$ methanol. The samples were mixed with the solvent (1:10), shaken for $30 \mathrm{~min}$, filtered through anhydrous sodium sulfate and vacuum-evaporated. The residue was dissolved in $80 \%$ methanol.

\section{Total phenolic contents}

The content of total phenolic compounds in the methanol extracts was determined by the Folin-Ciocalteu method (Siger et al., 2018). An aliquot $(0.025 \mathrm{ml})$ of the methanolic extract was placed in a volumetric flask
$(10 \mathrm{ml})$. Water $(5 \mathrm{ml})$ and the Folin-Ciocalteu reagent $(0.5 \mathrm{ml})$ were added. After $3 \mathrm{~min}$, saturated sodium carbonate $(1 \mathrm{ml})$ was added. The flask was filled with water up to $10 \mathrm{ml}$. After 1 hour, the solution absorbance was measured at $\lambda_{\max } 725 \mathrm{~nm}$ against a reagent blank using a UV-Vis spectrophotometer SP 8001 (Metertech Inc., Taipei, Taiwan). The total phenolic content was determined after preparation of a standard curve and on that basis the total phenolic compounds were measured as caffeic acid equivalents (CAE).

\section{Contents of phenolic compounds determined by HPLC}

The methanol extracts were subjected to acidic and basic hydrolyses. In the case of basic hydrolysis, $2.5 \mathrm{ml}$ of the extract were mixed with $3 \mathrm{ml}$ of $4 \mathrm{M} \mathrm{NaOH}$. The samples were then flushed with nitrogen and stirred for 4 hours at $4^{\circ} \mathrm{C}$. After that time, the $\mathrm{pH}$ of the solution was adjusted to 2 using $1 \mathrm{M} \mathrm{HCl}$. The whole volume was transferred to a $10 \mathrm{ml}$ volumetric flask. In the case of acidic hydrolysis, $2.5 \mathrm{ml}$ of the extract were mixed with $3 \mathrm{ml}$ of $1.1 \mathrm{M} \mathrm{HCl}$. The mixture was heated at $90^{\circ} \mathrm{C}$ for $20 \mathrm{~min}$. After cooling and neutralization, the mixture was transferred quantitatively to a $10 \mathrm{ml}$ volumetric flask. Before injection, all samples were filtered through a $0.45 \mathrm{~mm}$ syringe filter. Phenolic compounds were identified and quantified using RPHPLC (Waters, Milford, MA) on an XBridgeTM C18 column ( $4.6 \times 100 \mathrm{~mm}, 3.5 \mu \mathrm{m}$; Waters, Milford, MA) according to our previous method (Rokosik et al., 2019; Siger et al., 2012). Quantitative determination of phenolic compounds was carried out by comparing retention times and diode array spectral characteristics with the corresponding standards obtained from Sigma-Aldrich.

\section{Determination of Total Radical-Trapping Antioxidant Parameter (TRAP)}

The antioxidant activity of grains and selected grain products was determined using the Total Radical-Trapping Antioxidant Potential method. The source of peroxyl radicals was 2,2'-azobis(2-amidinopropane) dihydrochloride (AAPH) and a 2,7-dichlorodihydrofluorescein diacetate (DCFH-DA) fluorescence probe was the oxidizable substrate for free radicals. 2,7-Dichlorodihydrofluorescein (DCFH) was obtained as a result of DCFH-DA basic hydrolysis. Briefly, 
Nogala-Kałucka, M., Kawka, A., Dwiecki, K., Siger, A. (2020). Evaluation of bioactive compounds in cereals. Study of wheat, barley, oat and selected grain products. Acta Sci. Pol. Technol. Aliment., 19(4), 405-423. http://dx.doi.org/10.17306/J.AFS.2020.0858

$1.22 \mathrm{mg}$ of the fluorescence probe were dissolved in $1.5 \mathrm{ml}$ of dimethyl sulfoxide (DMSO) and $0.5 \mathrm{~mL}$ of $\mathrm{NaOH}(0.25 \mathrm{M})$ was added. The mixture was incubated for $30 \mathrm{~min}$ at room temperature $\left(22^{\circ} \mathrm{C}\right)$ and the $\mathrm{pH}$ was adjusted to 7.4. The obtained solution was diluted in $0.1 \mathrm{M}$ phosphate buffer ( $\mathrm{pH} 7.4$ ) to a final concentration of $100 \mathrm{mM}$. The antioxidant activity of the samples was measured by determining the time necessary for oxidation of the DCFH probe to highly fluorescent dichlorofluorescein (DCF) by free radicals generated from AAPH in the presence of extracts obtained from grains and grain products. Fluorescence was measured at $37^{\circ} \mathrm{C}$ in a cuvette containing $2.2 \mathrm{ml}$ of $0.1 \mathrm{M}$ phosphate buffer (pH 7.4), DCFH (4.25 mM), AAPH (8.5 mM) and $235 \mathrm{ml}$ of the extract. The excitation and emission wavelengths were $480 \mathrm{~nm}$ and $520 \mathrm{~nm}$, respectively. The TRAP value was expressed as micromoles of Trolox equivalents per kg d.m. (Siger et al., 2012).

\section{Statistical analysis}

The results are presented as means \pm standard deviation from three replicates of each experiment. The differences between the mean values were determined by the analysis of variance (ANOVA). The post-hoc analysis was performed using Tukey's test. The relationship between the analyzed variables was assessed by Pearson's correlation coefficient. Its significance was evaluated by Student's t-test. The intra-sample quantity variation of the samples was assayed using the Principal Component Analysis (PCA). The results in all the tests were considered significant at $p<0.05$.
The statistical analysis was performed using Statistica 10.0 software (StatSoft, Inc., Tulsa, OK).

\section{RESULTS AND DISCUSSION}

When assessing the quality of cereal grain as a versatile raw material, both physicochemical characteristics and health-promoting properties are taken into account, determining in this way its various applications for dietetic, medicinal and processing purposes. Knowledge of the physical properties of cereal grains is important when evaluating their technological, eating or feed quality. The quality characteristics of commercial wheat $(\mathrm{W})$, barley $(\mathrm{B})$ and oat $(\mathrm{O})$ grains are shown in Table 1. Hulled grains of the three cereals, i.e. wheat - W1, barley - B1 and oat - O1, were characterized by low moisture content and high purity, as evidenced by the minimal amounts of total impurities (Table 1). Moreover, the grains were shown to be clean, ripe, and free from damage (e.g. broken/ cracked/burned kernels) or foreign material. In addition, the grains were well-filled, healthy and met the quality requirements of grain for human consumption. W1 was characterized by good uniformity (73.8\%). In the case of nonwheat cereals such as B1 and O1, the mean value of this parameter was markedly different, being higher for B1 (93.5\%) than O1 (45.8\%). Regarding physical parameters such as test weight (TW) and 1000 kernel weight (TKW), significant differences were found between W1, B1 and O1 samples. Test weight (TW) is a measure of bulk density

Table 1. Quality parameters of commercial hulled grain samples - wheat, barley and oat

\begin{tabular}{|c|c|c|c|c|c|}
\hline $\begin{array}{l}\text { Moisture } \\
\%\end{array}$ & $\begin{array}{c}\text { Total impurities } \\
\%\end{array}$ & $\begin{array}{l}\text { Uniformity } \\
\%\end{array}$ & $\begin{array}{c}\text { Test weight }-\mathrm{TW} \\
\mathrm{kg} \cdot \mathrm{hl}^{-1}\end{array}$ & $\begin{array}{c}1000 \text { kernel } \\
\text { weight }- \text { TKW } \\
g\end{array}$ & $\begin{array}{c}\text { Falling } \\
\text { number } \\
\mathrm{s}\end{array}$ \\
\hline \multicolumn{6}{|c|}{ Wheat (W) } \\
\hline $12.7 \pm 0.1^{\mathrm{b}}$ & $2.2 \pm 0.1^{\mathrm{b}}$ & $73.8 \pm 0.9^{\mathrm{b}}$ & $78.7 \pm 0.6^{\mathrm{c}}$ & $41.3 \pm 0.4^{\mathrm{b}}$ & $313 \pm 6.4^{b}$ \\
\hline \multicolumn{6}{|c|}{ Barley (B) } \\
\hline $12.4 \pm 0.1^{\mathrm{b}}$ & $0.4 \pm 0.1^{\mathrm{a}}$ & $93.5 \pm 0.2^{\mathrm{c}}$ & $70.0 \pm 0.1^{b}$ & $53.0 \pm 1.2^{\mathrm{c}}$ & $249 \pm 2.8^{\mathrm{a}}$ \\
\hline \multicolumn{6}{|c|}{ Oat (O) } \\
\hline $11.1 \pm 0.1^{\mathrm{a}}$ & $3.1 \pm 0.2^{\mathrm{c}}$ & $45.8 \pm 9.0^{\mathrm{a}}$ & $56.2 \pm 0.3^{\mathrm{a}}$ & $37.5 \pm 2.1^{\mathrm{a}}$ & $382 \pm 3.5^{\mathrm{c}}$ \\
\hline
\end{tabular}

Values (means $\pm \mathrm{SD}, n=3$ ) bearing different superscripts are statistically significantly different $(P<0.05)$. 
Nogala-Kałucka, M., Kawka, A., Dwiecki, K., Siger, A. (2020). Evaluation of bioactive compounds in cereals. Study of wheat, barley, oat and selected grain products. Acta Sci. Pol. Technol. Aliment., 19(4), 405-423. http://dx.doi.org/10.17306/J.AFS.2020.0858

or the quantity of grain required to fill a specific volume. TW is part of the official Polish Standards for grain and a common test employed by food processors. It is also known as volumetric weight and is one of the simplest traditional criteria used to determine grain quality and measure grain bulk density. TW of $\mathrm{W} 1, \mathrm{~B} 1$ and $\mathrm{O} 1$ grains in this study ranged from 56.2 to $78.7 \mathrm{~kg} \cdot \mathrm{hl}^{-1}$. The mean values were statistically significantly different (Table 2), being higher in W1 $\left(78.7 \mathrm{~kg} \cdot \mathrm{hl}^{-1}\right)$ than in $\mathrm{B} 1\left(70.0 \mathrm{~kg} \cdot \mathrm{hl}^{-1}\right)$ and $\mathrm{O} 1(56.2$ $\left.\mathrm{kg} \cdot \mathrm{hl}^{-1}\right)$. These results confirm data reported by other authors (Boros et al., 2015; Gąsiorowski and Abdalla, 2004; Grzesiuk, 1988; Jankowski, 1988).

Grzesiuk (1988) reported that for wheat, barley and oat grains their bulk density (TW) values, expressed in $\mathrm{kg} \cdot \mathrm{m}^{-3}$, are in the range of 730-850, 580-700 and $400-550$, respectively. Studies on the quality assessment of different cereal varieties from Polish harvests in 2008-2012 showed that the average bulk density expressed as grain test weight of wheat, barley and oat was 79.1, 56.9 and $63.2 \mathrm{~kg} \cdot \mathrm{hl}^{-1}$, respectively (Boros et al., 2015). In turn, thousand kernel weight (TKW), as a basic parameter of grain cereal quality, informs us about the filling degree of the kernel with chemical components and its morphological structure, while it also determines the quantitative chemical composition of milling products (Boros et al., 2015; Grzesiuk, 1988). The highest TKW values were recorded for B1, while they were lowest in O1 (Table 1). According to this criterion the analyzed grain samples can be

Table 2. Chemical composition of wheat, barley, oat grains and their products, $\%$ d.m.

\begin{tabular}{|c|c|c|c|c|c|c|}
\hline Sample & Minerals & Protein* & Lipids & $\begin{array}{l}\text { Total dietary } \\
\text { fiber - TDF }\end{array}$ & Saccharides** & $\begin{array}{c}\text { Total } \\
\text { starch - TS }\end{array}$ \\
\hline \multicolumn{7}{|c|}{ Wheat (W) } \\
\hline Hulled (W1) & $1.55 \pm 0.02^{\mathrm{e}}$ & $13.2 \pm 0.01^{\mathrm{e}}$ & $1.85 \pm 0.08^{c}$ & $12.4 \pm 0.70^{\mathrm{c}, \mathrm{d}, \mathrm{e}}$ & 71.0 & $67.6 \pm 0.23^{\mathrm{d}, \mathrm{e}}$ \\
\hline Dehulled (W2) & $1.39 \pm 0.01^{\mathrm{d}}$ & $13.6 \pm 0.05^{\mathrm{f}}$ & $2.08 \pm 0.05^{\mathrm{d}}$ & $9.6 \pm 0.40^{\mathrm{b}}$ & 73.3 & $71.2 \pm 0.96^{\mathrm{fg} g}$ \\
\hline Middlings (W3) & $1.53 \pm 0.02^{\mathrm{e}}$ & $13.2 \pm 0.03^{\mathrm{e}}$ & $2.32 \pm 0.02^{\mathrm{e}}$ & $11.5 \pm 0.09^{\mathrm{c}}$ & 71.5 & $71.8 \pm 0.24^{\mathrm{f}, \mathrm{g}}$ \\
\hline Whole flour (W4) & $1.87 \pm 0.01^{\mathrm{f}, \mathrm{g}}$ & $13.2 \pm 0.02^{\mathrm{e}}$ & $2.43 \pm 0.02^{\mathrm{e}}$ & $13.7 \pm 0.60^{\mathrm{e}, \mathrm{f}}$ & 67.8 & $68.3 \pm 0.62^{\mathrm{e}}$ \\
\hline Flour type 550 (W5) & $0.63 \pm 0.01^{\mathrm{a}}$ & $11.7 \pm 0.09^{\mathrm{a}, \mathrm{b}}$ & $1.65 \pm 0.01^{\mathrm{b}}$ & $3.7 \pm 0.20^{\mathrm{a}}$ & 82.4 & $80.8 \pm 0.39^{i}$ \\
\hline \multicolumn{7}{|c|}{ Barley (B) } \\
\hline Hulled (B1) & $2.18 \pm 0.01^{\mathrm{h}}$ & $12.9 \pm 0.10^{\mathrm{d}}$ & $2.93 \pm 0.04^{\mathrm{f}}$ & $17.2 \pm 0.30^{\mathrm{g}}$ & 64.8 & $62.3 \pm 0.43^{b}$ \\
\hline Dehulled (B2) & $1.08 \pm 0.01^{\mathrm{b}}$ & $11.7 \pm 0.08^{\mathrm{a}, \mathrm{b}}$ & $1.90 \pm 0.02^{\mathrm{c}}$ & $12.0 \pm 0.90^{\mathrm{c}, \mathrm{d}}$ & 73.3 & $76.5 \pm 0.27^{\mathrm{h}}$ \\
\hline Middlings (B3) & $1.13 \pm 0.01^{\mathrm{b}}$ & $11.6 \pm 0.09^{\mathrm{a}}$ & $2.04 \pm 0.04^{\mathrm{d}}$ & $14.4 \pm 0.40^{\mathrm{f}}$ & 70.8 & $70.6 \pm 0.49^{\mathrm{f}}$ \\
\hline Whole flour (B4) & $1.22 \pm 0.01^{\mathrm{c}}$ & $12.2 \pm 0.07^{\mathrm{c}}$ & $1.44 \pm 0.03^{\mathrm{a}}$ & $13.5 \pm 0.50^{\mathrm{e}, \mathrm{f}}$ & 71.7 & $72.10 .30^{\mathrm{g}}$ \\
\hline \multicolumn{7}{|c|}{ Oat (O) } \\
\hline Hulled (O1) & $2.21 \pm 0.01^{\mathrm{h}}$ & $11.9 \pm 0.08^{\mathrm{b}}$ & $5.38 \pm 0.07^{\mathrm{g}}$ & $30.6 \pm 0.20^{\mathrm{h}}$ & 49.9 & $47.1 \pm 0.64^{\mathrm{a}}$ \\
\hline Dehulled (O2) & $1.89 \pm 0.00^{\mathrm{g}}$ & $14.6 \pm 0.10^{\mathrm{g}}$ & $7.40 \pm 0.05^{\mathrm{i}}$ & $13.1 \pm 0.20^{\mathrm{d}, \mathrm{e}, \mathrm{f}}$ & 63.0 & $65.4 \pm 0.44^{\mathrm{c}}$ \\
\hline Middlings (O3) & $1.82 \pm 0.05^{\mathrm{f}}$ & $13.8 \pm 0.03^{\mathrm{f}}$ & $7.37 \pm 0.04^{\mathrm{i}}$ & $11.5 \pm 0.10^{\mathrm{c}}$ & 65.5 & $66.5 \pm 0.22^{\mathrm{c}, \mathrm{d}}$ \\
\hline Whole flour (O4) & $1.82 \pm 0.01^{\mathrm{f}}$ & $14.7 \pm 0.09^{\mathrm{g}}$ & $6.82 \pm 0.06^{\mathrm{h}}$ & $10.1 \pm 0.50^{\mathrm{b}}$ & 66.6 & $66.8 \pm 0.24^{\mathrm{d}}$ \\
\hline Bran (O5) & $2.23 \pm 0.02^{\mathrm{h}}$ & $15.9 \pm 0.08^{\mathrm{h}}$ & $7.40 \pm 0.05^{\mathrm{i}}$ & $13.3 \pm 0.60^{\mathrm{d}, \mathrm{e}, \mathrm{f}}$ & 61.2 & $62.1 \pm 0.29^{\mathrm{b}}$ \\
\hline
\end{tabular}

Values (means $\pm \mathrm{SD}, n=3$ ) bearing different superscripts are statistically significantly different $(P<0.05)$.

$*$ Wheat $-N \times 5.7$, barley, oat $-N \times 6.25$.

$* *$ Calculated values. 
Nogala-Kałucka, M., Kawka, A., Dwiecki, K., Siger, A. (2020). Evaluation of bioactive compounds in cereals. Study of wheat, barley, oat and selected grain products. Acta Sci. Pol. Technol. Aliment., 19(4), 405-423. http://dx.doi.org/10.17306/J.AFS.2020.0858

presented in the following order: barley B1 $(53.0 \mathrm{~g})>$ wheat $\mathrm{W} 1(41.3 \mathrm{~g})>$ oat $\mathrm{O} 1(37.5 \mathrm{~g})$. Our results are different than those previously presented by Boros et al. (2015) for varieties of different cereal species registered on the Polish National List. Those authors reported that the average TKW values for wheat, barley and oat varieties from Polish harvests in 2008-2012 were $45.7,45.9$ and $31.4 \mathrm{~kg} \cdot \mathrm{hl}^{-1}$, respectively. TKW and TW are useful indexes for potential milling yield. The differences observed in both parameters between cereal varieties may be caused, among other things, by differences in the genetic makeup of these varieties and their growing conditions, as well as weather conditions, cultivation methods and harvest time, etc. (Mutwali et al., 2016). However, it should be emphasized that in this study the mass of commercial grains for the three cereal types was a mixture of different varieties grown in Poland. In samples W1, B1 and $\mathrm{O} 1$, the falling number values were within the range of 249-382 s, whereas the highest value was observed for sample O1 (382 s) at a conversely lower $\alpha$-amylase activity (Table 1). The results of the above assessment for selected quality parameters in unprocessed commercial grains of wheat, barley and oat indicate their good technological quality and suitability for processing.

Cereal grains for food production are subjected to mechanical treatment to prepare them for human consumption. For example, the elimination of the husk in the case of barley and oat grains significantly affects differences in the content of chemical components between hulled and dehulled grains of both cereals. Identification of the chemical composition of the grain after removal of the husk is very important for its further use in food processing. Mechanical processing of grain includes various unit operations, such as surface cleaning, dehulling and milling. As a result of these operations, anatomical parts of the kernel, e.g. the germ, the fruit and seed coats, are mechanically removed, which, as a consequence, reduces or increases the contents of nutrients and non-nutrients, affects the concentrations of bioactive components and modifies the bioavailability of these ingredients in the grain (Holtekjølen et al., 2011; Krejpcio et al., 2015; Liukkonen et al., 2003; Zieliński et al., 2012).

The chemical composition of commercial wheat, barley and oat grains along with their products is presented in Table 2. W1 grain, unlike $\mathrm{B} 1$ and $\mathrm{O} 1$ grains (Table 2), contained more protein (13.2\%), saccharides $(71.0 \%)$ and total starch (TS; 67.6\%), and less minerals $(1.55 \%)$, lipids (1.85\%) and total dietary fiber (TDF; $12.38 \%$ ). In the non-wheat B1 and O1 samples, the protein content was 12.9 and $11.9 \%$ respectively, while the content of minerals $(2.2 \%)$ was identical. The contents of lipids and TDF were markedly lower in B1 (2.93 and 17.23\%) compared to O1 (5.38 and $30.61 \%$ ), whereas in the $\mathrm{O} 1$ sample the lowest amounts of saccharides and TS (49.9 and 47.1\%) were found (Table 2). It was observed that the content of minerals, lipids and TDF in B1 and $\mathrm{O} 1$ was 1.4, 2.3 (1.6-2.9) and $1.9(1.4-2.5)$ times greater than in $\mathrm{W} 1$. Dehulling of the W1, B1 and O1 grains significantly contributed to the reduction of minerals, protein and TDF contents in the W2, B2 and O2 samples, except for the amount of protein in $\mathrm{W} 2$ and $\mathrm{O} 2$ (Table 2). While in W1 the content of minerals and TDF was higher than in W2 (by 10\% and 23\%, respectively), W2 contained greater amounts of lipids, saccharides and TS. Wheat products $\mathrm{W} 3, \mathrm{~W} 4$ and $\mathrm{W} 5$, obtained during the processing of W2 grain, showed significant differences in their levels of nutrients (Table 2). Among the studied samples W3, W4 and W5, the greatest amounts of minerals, protein, lipids and TDF were recorded in $\mathrm{W} 4$ (1.87, 13.2, 2.43 and 13.7\%), while they were lowest in W5 $(0.63,11.7,1.65$ and $3.7 \%$, respectively). Furthermore, $\mathrm{W} 4$, in contrast to W3 and W5, was characterized by limited levels of saccharides and TS. W5, as an all-purpose wheat flour, in comparison with $\mathrm{W} 3$ and $\mathrm{W} 4$, had the lowest contents of minerals, proteins, lipids and TDF at the highest amounts of saccharides and TS. It should be noted that if the flour is refined, it contains more starch and less nutrients (proteins, lipids, minerals), dietary fiber, $\mathrm{B}$ vitamins and other antioxidants. Therefore, the socalled "white" bread flours (wheat and rye) are less valuable from the point of view of human nutrition (Fardet, 2010; Gąsiorowski and Abdalla, 2004; Khan, 2009; Zieliński et al., 2012).

The hulled B1 and $\mathrm{O} 1$ grains, in comparison with $\mathrm{W} 1$, contained greater amounts of minerals, lipids and TDF, at lower levels of saccharides and TS. However, in $\mathrm{O} 1$ there were higher contents of lipids (by $45 \%$ ) and TDF (by 44\%) compared to those in B1 at lower levels of protein (by 8\%), saccharides and TS 
(by 14\%). The B1 grain was characterized by greater contents of minerals, protein, lipids, TDF and lower levels of saccharides and TS than grain B2 (Table 2). The B3 and B4 barley products obtained during the processing of $\mathrm{B} 2$ grain, differed in their amounts of chemical components, with slightly higher contents of minerals and protein, and lower lipid levels were recorded in sample B4. Samples B3 and B4 contained more TDF, lower amounts of saccharides and TS in comparison with B2 (Table 2). The O1 grain had greater contents of minerals and TDF at lower levels of protein, lipids, saccharides and TS compared to the $\mathrm{O} 2$ grain (Table 2). Oat products, i.e. $\mathrm{O} 3$ and $\mathrm{O} 4$, obtained during the processing of $\mathrm{O} 2$ grain, showed greater variation in their amounts of chemical components in comparison to barley products B3 and B4. In the $\mathrm{O} 3$ sample, when compared to the $\mathrm{O} 4$ sample, the content of minerals was similar, while the amount of protein was lower (by 6\%) as the levels of lipids, TDF and saccharides increased by 7,12 and $2 \%$, respectively. The $\mathrm{O} 5$ oat bran, in contrast to $\mathrm{O} 2, \mathrm{O} 3$ and $\mathrm{O} 4$, was characterized by the highest content of minerals $(2.2 \%)$, protein $(16 \%)$ and TDF $(13 \%)$ at the smallest amounts of saccharides $(61 \%)$ and TS $(62 \%)$. Grain dehulling in the three cereals W1, B1 and O1 significantly differentiated the contents of chemical components in samples $\mathrm{W} 2, \mathrm{~B} 2, \mathrm{O} 2$. This treatment reduced the amounts of minerals in $\mathrm{W} 2, \mathrm{~B} 2$ and $\mathrm{O} 2$ (by $9.2,50.5$ and $14.5 \%$ ), while in the case of proteins this only occurred in B2 (by 9.3\%); moreover, it resulted in a decreased TDF content (by 19.4, 30.2 and $57.2 \%$, respectively). In contrast, contents of saccharides, TS and lipids increased, but only in the $\mathrm{W} 2$ and $\mathrm{O} 2$ samples. The lowest levels of saccharides and TS were recorded in the $\mathrm{O} 2$ sample, while the lowest lipid contents were found in samples W2 and B2. Dehulled $\mathrm{O} 2$ grain, in comparison to $\mathrm{W} 2$ and $\mathrm{B} 2$, at a comparable amount of protein contained a 3.5-fold higher level of lipids, but lower amounts of saccharides and starch. It should be noted that nutrients are distributed relatively uniformly in the oat kernel (Table 2), thus there are no major differences in the chemical composition between the raw material ( $\mathrm{O} 2$ grain) and oat products $(\mathrm{O} 3, \mathrm{O} 4)$. The studied commercial cereal raw materials are characterized by a different chemical composition. Thus, the type of cereal grains and the adopted processing method both have a significant impact on nutrient contents in cereal products (Baik and Ullrich, 2008; Butt et al., 2008; Doehlert and Moore, 1997; Newman and Newman, 2008).

The contents of total dietary fiber (TDF) as well as its insoluble (IDF) and soluble (SDF) fractions in wheat, barley, oat grains and their products are presented in Tables 2 and 3. In the $\mathrm{W} 1, \mathrm{~B} 1$ and $\mathrm{O} 1$ grains, the TDF content was $12.4,17.2$ and $30.6 \%$, respectively (Table 2). Among the TDF components, the lowest levels of both the insoluble (IDF) and soluble (SDF) fractions were recorded for the W1 sample (11.1 and $1.3 \mathrm{~g} / 100 \mathrm{~g} \mathrm{d.m}$.), while they were highest in the $\mathrm{O} 1$ sample (27.5 and $3.1 \mathrm{~g} / 100 \mathrm{~g}$ d.m.; Table 3). Samples B1 and O1 were the richest sources of SDF, being a valuable ingredient from a nutritional point of view. The percentage content of SDF in TDF was higher in $\mathrm{B} 1$ (15) than $\mathrm{O} 1$ (12). In samples $\mathrm{W} 1, \mathrm{~B} 1$ and O1 the content of $\beta$-glucans ( $\beta$-GLU; Table 3 ) ranged from 0.8 to $4.5 \mathrm{~g} / 100 \mathrm{~g} \mathrm{~d}$.m., whereas it was higher in B1 (4.5 g/100 g d.m.) and O1 (3.1 g/100 g d.m.). The lowest total arabinoxylans (total $\mathrm{AX}$ ) and their water-unextractable contents (WU-AX) were found in the W1 sample (6.7 and $5.4 \mathrm{~g} / 100 \mathrm{~g}$ d.m.), whereas they were highest in $\mathrm{O} 1$ (11.3 and $10.9 \mathrm{~g} / 100 \mathrm{~g}$ d.m., respectively). The level of water-extractable arabinoxylans (WE-AX) ranged from 0.4 to $1.3 \mathrm{~g} / 100 \mathrm{~g}$ d.m., with the latter value detected in the $\mathrm{W} 1$ sample.

Wheat is relatively poor in soluble fiber, which is mainly found in the form of water-extractable arabinoxylans (Boros et al., 2015). It has been demonstrated that in whole wheat grain the SDF (Fardet, 2010): IDF ratio is $1: 5$, at large amounts of IDF (up to 11 $\mathrm{g} / 100 \mathrm{~g}$ ). It needs to be emphasized here that in the case of wheat bran and wheat germ it is $1: 10$ and 1:3, respectively. Therefore, wholegrain wheat is the factor responsible to the greatest extent for the functional effects of dietary fiber, which regulates fat and carbohydrate metabolism in the human body (Boros et al., 2015). Dehulling of W1, B1 and O1 grain significantly reduced the contents of dietary fiber and its components in dehulled W2, B2 and O2 kernels (Tables 2, 3). The TDF content in the $\mathrm{W} 2, \mathrm{~B} 2$ and $\mathrm{O} 2$ samples $(9.6,12.0$ and $13.1 \%)$ was reduced by $22.5,30.2$ and $57.2 \%$, respectively, when compared to $\mathrm{W} 1, \mathrm{~B} 1$ and $\mathrm{O} 1$. The tested dehulled $\mathrm{W} 2, \mathrm{~B} 2$ and $\mathrm{O} 2$ samples were significantly different in terms of their contents of IDF and SDF, $\beta$-GLU and total AX, including WU-AX 
Nogala-Kałucka, M., Kawka, A., Dwiecki, K., Siger, A. (2020). Evaluation of bioactive compounds in cereals. Study of wheat, barley, oat and selected grain products. Acta Sci. Pol. Technol. Aliment., 19(4), 405-423. http://dx.doi.org/10.17306/J.AFS.2020.0858

Table 3. The content of dietary fiber and its components in grains of wheat, barley, oats and their products, g/100 g d.m.

\begin{tabular}{|c|c|c|c|c|c|c|c|c|}
\hline \multirow[b]{2}{*}{ Raw materials } & \multicolumn{2}{|c|}{ Dietary fiber } & \multirow[b]{2}{*}{$\begin{array}{l}\text { Percent } \\
\text { of SDF } \\
\text { in TDF }\end{array}$} & \multirow[b]{2}{*}{$\begin{array}{c}\beta \text {-glucans - } \\
\beta \text {-GLU }\end{array}$} & \multicolumn{3}{|c|}{ Arabinoxylans - AX } & \multirow[b]{2}{*}{$\begin{array}{c}\text { AX total } \\
\beta-G L U\end{array}$} \\
\hline & $\begin{array}{c}\text { insoluble } \\
\text { dietary } \\
\text { fiber - IDF }\end{array}$ & $\begin{array}{c}\text { soluble } \\
\text { dietary } \\
\text { fiber - SDF }\end{array}$ & & & AX total & $\begin{array}{c}\text { soluble } \\
\text { in water - } \\
\text { WE-AX }\end{array}$ & $\begin{array}{c}\text { insoluble } \\
\text { in water - } \\
\text { WU-AX }\end{array}$ & \\
\hline \multicolumn{9}{|c|}{ Wheat (W) } \\
\hline Hulled (W1) & $11.1 \pm 0.61^{\mathrm{h}, \mathrm{i}}$ & $1.3 \pm 0.09^{\mathrm{a}}$ & - & $0.8 \pm 0.02^{\mathrm{b}}$ & $6.7 \pm 0.2^{\mathrm{e}}$ & $1.3 \pm 0.0^{\mathrm{c}, \mathrm{d}}$ & $5.4 \pm 0.0^{\mathrm{h}}$ & 8.4 \\
\hline Dehulled (W2) & $8.4 \pm 0.27^{\mathrm{d}, \mathrm{e}}$ & $1.2 \pm 0.12^{\mathrm{a}}$ & - & $0.7 \pm 0.01^{\mathrm{b}}$ & $5.8 \pm 0.2^{\mathrm{d}}$ & $1.4 \pm 0.1^{\mathrm{d}}$ & $4.4 \pm 0.1^{\mathrm{g}}$ & 8.3 \\
\hline Middlings (W3) & $10.2 \pm 0.02^{\mathrm{g}, \mathrm{h}}$ & $1.3 \pm 0.10^{\mathrm{a}}$ & - & $0.8 \pm 0.02^{\mathrm{b}}$ & $5.7 \pm 0.2^{\mathrm{d}}$ & $1.3 \pm 0.1^{\mathrm{c}, \mathrm{d}}$ & $4.4 \pm 0.1^{\mathrm{g}}$ & 7.1 \\
\hline Whole flour (W4) & $11.8 \pm 0.53^{\mathrm{i}}$ & $1.9 \pm 0.10^{\mathrm{a}, \mathrm{b}}$ & - & $0.8 \pm 0.02^{\mathrm{b}}$ & $7.8 \pm 0.1^{g}$ & $1.2 \pm 0.0^{\mathrm{c}}$ & 6.6. $\pm 0.0^{\mathrm{i}}$ & 9.8 \\
\hline Flour type 550 (W5) & $2.5 \pm 0.09^{\mathrm{a}}$ & $1.2 \pm 0.13^{\mathrm{a}}$ & - & $0.4 \pm 0.03^{\mathrm{a}}$ & $3.0 \pm 0.1^{\mathrm{a}}$ & $1.2 \pm 0.0^{\mathrm{c}}$ & $1.8 \pm 0.1^{\mathrm{a}}$ & 7.5 \\
\hline \multicolumn{9}{|c|}{ Barley (B) } \\
\hline Hulled (B1) & $14.6 \pm 0.24^{j}$ & $2.6 \pm 0.28^{b, c}$ & 15 & $4.5 \pm 0.02^{\mathrm{e}}$ & $7.2 \pm 0.3^{\mathrm{f}}$ & $0.5 \pm 0.0^{\mathrm{b}}$ & $6.7 \pm 0.2^{\mathrm{i}}$ & 1.6 \\
\hline Dehulled (B2) & $6.7 \pm 0.24^{\mathrm{b}, \mathrm{c}}$ & $5.3 \pm 0.64^{\mathrm{g}}$ & 44 & $5.3 \pm 0.05^{\mathrm{f}}$ & $3.6 \pm 0.1^{\mathrm{b}}$ & $0.4 \pm 0.0^{\mathrm{a}, \mathrm{b}}$ & $3.2 \pm 0.0^{\mathrm{d}, \mathrm{e}}$ & 0.7 \\
\hline Middlings (B3) & $10.1 \pm 0.45^{\mathrm{g}}$ & $4.4 \pm 0.17^{\mathrm{f}}$ & 31 & $5.1 \pm 0.02^{\mathrm{f}}$ & $3.7 \pm 0.2^{\mathrm{b}}$ & $0.4 \pm 0.0^{\mathrm{a}, \mathrm{b}}$ & $3.3 \pm 0.1^{\mathrm{e}}$ & 0.7 \\
\hline Whole flour (B4) & $9.4 \pm 0.29^{\mathrm{f}, \mathrm{g}}$ & $4.1 \pm 0.37^{\mathrm{e}, \mathrm{f}}$ & 30 & $3.8 \pm 0.06^{\mathrm{d}}$ & $4.4 \pm 0.0^{c}$ & $0.4 \pm 0.0^{\mathrm{a}, \mathrm{b}}$ & $4.0 \pm 0.0^{\mathrm{f}}$ & 1.2 \\
\hline \multicolumn{9}{|c|}{ Oat $(\mathrm{O})$} \\
\hline Hulled (O1) & $27.5 \pm 0.17^{\mathrm{k}}$ & $3.1 \pm 0.14^{\mathrm{c}, \mathrm{d}}$ & 12 & $3.1 \pm 0.01^{\mathrm{c}}$ & $11.3 \pm 0.2^{\mathrm{h}}$ & $0.4 \pm 0.0^{\mathrm{a}, \mathrm{b}}$ & $10.9 \pm 0.1^{\mathrm{j}}$ & 3.7 \\
\hline Dehulled (O2) & $10.3 \pm 0.02^{\mathrm{g}, \mathrm{h}}$ & $2.8 \pm 0.23^{\mathrm{c}, \mathrm{d}}$ & 21 & $4.6 \pm 0.00^{\mathrm{e}}$ & $3.1 \pm 0.1^{\mathrm{a}}$ & $0.3 \pm 0.0^{\mathrm{a}}$ & $2.8 \pm 0.0^{\mathrm{b}, \mathrm{c}}$ & 0.7 \\
\hline Middlings (O3) & $7.6 \pm 0.06^{\mathrm{c}, \mathrm{d}}$ & $3.9 \pm 0.10^{\mathrm{e}, \mathrm{f}}$ & 34 & $3.8 \pm 0.23^{\mathrm{d}}$ & $3.1 \pm 0.1^{\mathrm{a}}$ & $0.3 \pm 0.0^{\mathrm{a}}$ & $2.8 \pm 0.1^{\mathrm{b}, \mathrm{c}}$ & 0.8 \\
\hline Whole flour (O4) & $6.6 \pm 0.31^{\mathrm{b}}$ & $3.5 \pm 0.14^{\mathrm{d}, \mathrm{e}}$ & 35 & $3.8 \pm 0.03^{\mathrm{d}}$ & $3.1 \pm 0.1^{\mathrm{a}}$ & $0.4 \pm 0.0^{\mathrm{a}, \mathrm{b}}$ & $2.7 \pm 0.1^{\mathrm{b}}$ & 0.8 \\
\hline Bran (O5) & $8.7 \pm 0.49^{\mathrm{e}, \mathrm{f}}$ & $4.6 \pm 0.18^{\mathrm{f}, \mathrm{g}}$ & 35 & $5.2 \pm 0.25^{\mathrm{f}}$ & $3.3 \pm 0.1^{\mathrm{a}, \mathrm{b}}$ & $0.3 \pm 0.0^{\mathrm{a}}$ & $3.0 \pm 0.0^{\mathrm{c}, \mathrm{d}}$ & 0.6 \\
\hline
\end{tabular}

Values (means $\pm \mathrm{SD}, n=3$ ) bearing different superscripts are statistically significantly different $(P<0.05)$.

The content of AX is given on the anhydrous xylose present in the AX chain.

(Table 3). The W2 grain contained $8.4 \mathrm{~g} / 100 \mathrm{~g}$ d.m. IDF, whereas in $\mathrm{B} 2$ and $\mathrm{O} 2$ the IDF values were 6.7 and $10.3 \mathrm{~g} / 100 \mathrm{~g}$ d.m., respectively. The SDF content was the lowest in W2 (1.2 g/100 g d.m.), while it was over 2- to 4-fold greater in $\mathrm{O} 2$ (2.8 g/100 g d.m.) and B2 (5.3 g/100 g d.m.). Similarly, the $\beta$-GLU content was relatively low in the $\mathrm{W} 2$ sample $(0.7 \mathrm{~g} / 100 \mathrm{~g}$ d.m. $)$, whereas it was several times higher in B2 $(5.3 \mathrm{~g} / 100$ g d.m.) and $\mathrm{O} 2$ (4.6 g/100 g d.m.). In the W2, B2 and O2 samples the total AX content was 5.8, 3.6 and 3.1 $\mathrm{g} / 100 \mathrm{~g}$ d.m., respectively (Table 3 ). The results of these analyses indicate that dehulled $\mathrm{W} 2, \mathrm{~B} 2$ and $\mathrm{O} 2$ grains contain significantly less WE-AX than WU-AX. The WE-AX content ranged from 0.3 (B2) to
$1.4 \mathrm{~g} / 100 \mathrm{~g}$ d.m. (W2), while for WU-AX it was from $2.8 \mathrm{~g} / 100 \mathrm{~g}$ d.m. (O2) up to $4.4 \mathrm{~g} / 100 \mathrm{~g} \mathrm{d.m}$. (W2). The dehulled B2 and $\mathrm{O} 2$ grains, in contrast to the W2 grain, contained greater amounts of SDF and $\beta-G L U$, i.e. nutrients valuable from a nutritional point of view, at lower levels of total AX, WE-AX and WU-AX.

Among the many types of cereals, oat and barley grains are rich in $\beta$-glucans, while rye contains an intermediate quantity and wheat has a low level of these compounds (Boros et al., 2015; Frølich et al., 2013). In wheat, unlike barley and oats, mainly water-extractable arabinoxylans form the soluble dietary fiber fraction, which, similar to $\beta$-glucans, forms viscous solutions in an aqueous environment. Literature 
on the subject has shown that different cereals and their varieties vary in their nutrient contents. This fact is related to the influence of genetic factors, climatic and soil conditions, cultivation and harvesting technology, storage conditions, etc. (Boros et al., 2015; Grzesiuk, 1988; Idehen et al., 2017; Newman and Newman, 2008; van den Broeck et al., 2015). Wheat products $\mathrm{W} 3$ and $\mathrm{W} 4$, obtained from dehulled grain W2, contained 11.5 and $13.7 \%$ TDF, respectively, including 10.2 and $11.8 \mathrm{~g} / 100 \mathrm{~g}$ d.m. IDF, as well as 1.3 and $1.9 \mathrm{~g} / 100 \mathrm{~g}$ d.m. SDF (Tables 2, 3). In the W5 sample, obtained during milling of W2 grain, the TDF, IDF and SDF contents were 3.7, 2.5 and $1.2 \mathrm{~g} / 100 \mathrm{~g}$ d.m., respectively. The $\beta$-GLU level was similar in W3 and W4 (0.8 g/100 g d.m.), while it was lower in W5 $(0.4 \mathrm{~g} / 100 \mathrm{~g}$ d.m.). The W3 and W4 samples contained greater levels of total AX and WU-AX than the W5 sample. In contrast, the WE-AX content was similar in the tested W3, W4 and W5 samples (Table 3). In the barley products, i.e. middling's B3 and whole flour $\mathrm{B} 4$, obtained from dehulled grain $\mathrm{B} 2$, the TDF content was in the range of $13.5-14.4 \mathrm{~g} / 100 \mathrm{~g}$ d.m., being higher in B3 (Table 2). Average levels of the IDF and SDF fractions (Table 3) were greater in B3 (10.1 and $4.4 \mathrm{~g} / 100 \mathrm{~g}$ d.m.) than in B4 (9.4 and $4.1 \mathrm{~g} / 100 \mathrm{~g}$ d.m., respectively). It should be emphasized that the percentage content of SDF in TDF in the hulled B1 grain amounting to $15 \%$ was lower than that in the dehulled B2 grain (44\%) or the other barley products. In barley samples B3 and B4 the SDF fraction constituted 31 and $30 \%$ of the total TDF content, respectively. In B3 and B4 the $\beta$-GLU content was 5.1 and $3.8 \%$, respectively, both values being lower than that in $\mathrm{B} 2(5.3 \%)$. The mean levels of total arabinoxylans (AX) and the WU-AX fraction were 3.6 and $3.2 \mathrm{~g} / 100 \mathrm{~g}$ d.m., respectively, in sample B2, 3.7 and $3.3 \mathrm{~g} / 100 \mathrm{~g} \mathrm{d.m}$. in sample B3 and 4.4 and $4.0 \mathrm{~g} / 100 \mathrm{~g}$ d.m. in B4. In turn, identical WE-AX contents $(0.4 \mathrm{~g} / 100 \mathrm{~g}$ d.m. $)$ were found in the tested B2, B3 and B4 samples (Table 3). Oat products, i.e. ground grain $\mathrm{O} 3$, whole flour $\mathrm{O} 4$ and bran $\mathrm{O} 5$, obtained from dehulled $\mathrm{O} 2$ grains, contained $11.5,10.1$ and $13.3 \%$ of TDF, respectively, thus the highest level of that fraction was recorded in the O5 sample (Table 2). Average amounts of the IDF and SDF fractions were varied. Their highest contents (Table 3) were found in $\mathrm{O} 5$ (8.7 and $4.6 \mathrm{~g} / 100 \mathrm{~g} \mathrm{~d}$ d.m.), while they were lower in $\mathrm{O} 3$ (7.6 and $3.9 \mathrm{~g} / 100 \mathrm{~g}$ d.m.) and
$\mathrm{O} 4$ (6.6 and $3.5 \mathrm{~g} / 100 \mathrm{~g}$ d.m.). The percentage content of SDF in TDF in the hulled O1 grain was $10 \%$ and it was lower than in the dehulled $\mathrm{O} 2$ grain $(21 \%)$ or the other oat products (Table 3). In samples $\mathrm{O} 3, \mathrm{O} 4$ and O5 the SDF fraction accounted for 34,35 and $35 \%$ of the total TDF content, respectively.

The $\beta$-GLU content was $3.8 \mathrm{~g} / 100 \mathrm{~g}$ d.m. in the $\mathrm{O} 3$ and $\mathrm{O} 4$ samples and it was lower than in $\mathrm{O} 2(4.6 \mathrm{~g} / 100 \mathrm{~g}$ d.m.). In $\mathrm{O} 3$ and $\mathrm{O} 4$ the mean levels of total AX, WE$-\mathrm{AX}$ and WU-AX were similar to their amounts in the $\mathrm{O} 2$ grain. In $\mathrm{O} 3$ and $\mathrm{O} 4$ the mean values of total $\mathrm{AX}$, WE-AX and WU-AX were comparable, being identical to that in the $\mathrm{O} 2$ grain. The $\mathrm{O} 5$ sample contained $5.2 \mathrm{~g} / 100 \mathrm{~g}$ d.m. $\beta$-GLU and 3.3, 0.3 and $3.0 \mathrm{~g} / 100 \mathrm{~g}$ d.m. of total AX, WE AX and WU-AX, respectively (Table 3). Kawka (2004) showed that the ratio of total AX to $\beta$-GLU contents ranges from 1.4 to 1.7 in grain of eight Polish barley cultivars grown in Western Poland. In turn, Henry (1985) reported the above ratio in wheat, barley and oat grains to be 5.5, 1.3 and 2.3, respectively. When examining the chemical composition of 57 wheat varieties from 3 different agroclimatic regions of Poland, Boros et al. (2015) showed that the content of nutrients and other bioactive compounds in wheat grain is a varietal trait, determined genetically, but modified by the environmental conditions under which a given cereal was cultivated. Fardet (2010) reported that the grain refining process may lead to losses of dietary fiber (58\%), minerals $(\mathrm{Mg}-83 \%$, $\mathrm{Zn}-79 \%$, Se $-92 \%)$, niacin $(70 \%)$, folate $(61 \%)$ and vitamin E (79\%) in cereal products. Thus, the so-called white flours, as highly processed products, are characterized by a decreased nutritional value in comparison with whole-grain flours (low-processed wholemeal flours). Wholegrain cereal products contain a much larger range of compounds with a potential antioxidant effect than refined milling products.

In this study, the content of native lipophilic and hydrophilic antioxidants was also tested, with data shown in Tables 4-6. The samples were analyzed by HPLC to identify $\alpha$-, $\beta$ - and $\delta$-tocopherols $(\alpha-\mathrm{T}, \beta$-T, $\delta$-T) found in cereal materials. As a result, homologues of $\alpha-T$, $\beta$-T (mainly in wheat and barley) and $\delta$-T (only in barley), as well as $\alpha$ - and $\beta$-tocotrienols ( $\alpha$-T3 and $\beta$-T3) were detected. In the hulled $\mathrm{W} 1, \mathrm{~B} 1$ and $\mathrm{O} 1$ grains the tocopherol content (Table 4), expressed as $\mathrm{mg} / 100 \mathrm{~g}$, was higher in sample B1 (1.6) than in W1 (1.3) and 
Nogala-Kałucka, M., Kawka, A., Dwiecki, K., Siger, A. (2020). Evaluation of bioactive compounds in cereals. Study of wheat, barley, oat and selected grain products. Acta Sci. Pol. Technol. Aliment., 19(4), 405-423. http://dx.doi.org/10.17306/J.AFS.2020.0858

Table 4. The content of tocopherol and tocotrienol homologues in grains of wheat, barley, oats and their products, $\% \mathrm{~d} . \mathrm{m}$.

\begin{tabular}{|c|c|c|c|c|c|c|}
\hline \multirow{2}{*}{ Sample } & \multicolumn{6}{|c|}{ Tocochromanol content, mg/100 g d.m. } \\
\hline & $\alpha-T$ & $\alpha-\mathrm{T} 3$ & $\beta-\mathrm{T}$ & $\beta-\mathrm{T} 3$ & $\delta-\mathrm{T}$ & total \\
\hline \multicolumn{7}{|c|}{ Wheat (W) } \\
\hline Hulled (W1) & $0.93 \pm 0.01^{\mathrm{f}}$ & $0.33 \pm 0.04^{\mathrm{a}, \mathrm{b}}$ & $0.39 \pm 0.06^{\mathrm{c}}$ & $2.99 \pm 0.24^{\mathrm{f}}$ & - & 4.64 \\
\hline Dehulled (W2) & $0.69 \pm 0.03^{\mathrm{e}}$ & $0.31 \pm 0.09^{\mathrm{a}, \mathrm{b}}$ & $0.36 \pm 0.09^{\mathrm{c}}$ & $2.72 \pm 0.15^{\mathrm{e}, \mathrm{f}}$ & - & 4.08 \\
\hline Middlings (W3) & $0.69 \pm 0.14^{\mathrm{e}}$ & $0.15 \pm 0.02^{\mathrm{a}}$ & $0.29 \pm 0.11^{\mathrm{b}, \mathrm{c}}$ & $2.63 \pm 0.13^{\mathrm{e}}$ & - & 3.76 \\
\hline Whole flour (W4) & $0.64 \pm 0.10^{\mathrm{d}, \mathrm{e}}$ & $0.20 \pm 0.02^{\mathrm{a}}$ & $0.35 \pm 0.12^{\mathrm{c}}$ & $2.98 \pm 0.18^{\mathrm{f}}$ & - & 4.17 \\
\hline Flour type 550 (W5) & $0.21 \pm 0.01^{\mathrm{a}}$ & $0.05 \pm 0.01^{\mathrm{a}}$ & $0.12 \pm 0.05^{\mathrm{a}, \mathrm{b}}$ & $1.97 \pm 0.17^{\mathrm{d}}$ & - & 2.35 \\
\hline \multicolumn{7}{|c|}{ Barley (B) } \\
\hline Hulled (B1) & $0.70 \pm 0.01^{\mathrm{e}}$ & $1.72 \pm 0.25^{\mathrm{f}}$ & $0.36 \pm 0.10^{\mathrm{c}}$ & $0.56 \pm 0.01^{\mathrm{b}, \mathrm{c}}$ & $0.55 \pm 0.24$ & 3.89 \\
\hline Dehulled (B2) & $0.19 \pm 0.06^{\mathrm{a}}$ & $0.68 \pm 0.01^{\mathrm{b}, \mathrm{c}}$ & $0.28 \pm 0.01^{\mathrm{b}, \mathrm{c}}$ & $0.35 \pm 0.06^{\mathrm{a}, \mathrm{b}, \mathrm{c}}$ & trace & 1.50 \\
\hline Middlings (B3) & $0.24 \pm 0.08^{\mathrm{a}, \mathrm{b}}$ & $0.83 \pm 0.11^{\mathrm{c}, \mathrm{d}}$ & $0.36 \pm 0.01^{\mathrm{c}}$ & $0.57 \pm 0.07^{\mathrm{c}}$ & trace & 2.00 \\
\hline Whole flour (B4) & $0.44 \pm 0.11^{\mathrm{b}, \mathrm{c}, \mathrm{d}}$ & $1.29 \pm 0.16^{\mathrm{e}}$ & $0.31 \pm 0.06^{\mathrm{c}}$ & $0.55 \pm 0.02^{\mathrm{b}, \mathrm{c}}$ & trace & 2.59 \\
\hline \multicolumn{7}{|c|}{ Oat $(\mathrm{O})$} \\
\hline Hulled (O1) & $0.51 \pm 0.02^{\mathrm{d}, \mathrm{e}}$ & $1.39 \pm 0.23^{\mathrm{e}, \mathrm{f}}$ & $0.07 \pm 0.01^{\mathrm{a}}$ & $0.25 \pm 0.06^{\mathrm{a}, \mathrm{b}}$ & - & 2.22 \\
\hline Dehulled (O2) & $0.48 \pm 0.01^{\mathrm{c}, \mathrm{d}}$ & $1.28 \pm 0.15^{\mathrm{e}}$ & - & $0.27 \pm 0.01^{\mathrm{a}, \mathrm{b}, \mathrm{c}}$ & - & 2.03 \\
\hline Middlings (O3) & $0.47 \pm 0.04^{\mathrm{c}, \mathrm{d}}$ & $1.22 \pm 0.24^{\mathrm{d}, \mathrm{e}}$ & - & $0.17 \pm 0.08^{\mathrm{a}}$ & - & 1.86 \\
\hline Whole flour (O4) & $0.45 \pm 0.06^{\mathrm{c}, \mathrm{d}}$ & $1.26 \pm 0.11^{\mathrm{e}}$ & - & $0.23 \pm 0.03^{\mathrm{a}, \mathrm{b}}$ & - & 1.94 \\
\hline Bran (O5) & $0.28 \pm 0.08^{\mathrm{a}, \mathrm{b}, \mathrm{c}}$ & $1.35 \pm 0.16^{\mathrm{e}, \mathrm{f}}$ & - & $0.27 \pm 0.04^{\mathrm{a}, \mathrm{b}, \mathrm{c}}$ & - & 1.90 \\
\hline
\end{tabular}

Values (means $\pm \mathrm{SD}, n=3$ ) bearing different superscripts are statistically significantly different $(P<0.05)$.

O1 (0.6). In the tocopherol group in the $\mathrm{W} 1$ grain, $\alpha$-tocopherol $(\alpha-\mathrm{T})$, a homologue with the highest biological activity, was predominant. The grain samples tested in terms of their $\alpha$-T contents may be ordered as follows: wheat $\mathrm{W} 1(0.9 \%)>$ barley B1 $(0.7 \%)>$ oats O1 $(0.5 \%)$. In the W1 sample tocotrienols constituted $72 \%$ of all tocochromanols, while the amount of $\beta-\mathrm{T} 3$ accounted for $64 \%$ of all tocochromanols. The tocopherol content in $\mathrm{B} 1$ was more than 2.5-fold higher than in O1. In B1 the content of tocopherols was more than 2.5 times higher than in O1. In the B1 sample three homologues, i.e. $\alpha-\mathrm{T}, \beta-\mathrm{T}$ and $\delta$-T, were identified, accounting for $41 \%$ of the total tocochromanols. In turn, in $\mathrm{O} 1$ only $\alpha-\mathrm{T}$ and $\beta-\mathrm{T}(0.5$ and $0.07 \mathrm{mg} / 100 \mathrm{~g})$ were detected, but their values were lower than in B1 $(\alpha-\mathrm{T}-$ $0.7 \mathrm{mg} / 100 \mathrm{~g}$ and $\beta-\mathrm{T}-0.4 \mathrm{mg} / 100 \mathrm{~g})$. The content of tocotrienols $(\alpha-\mathrm{T} 3, \beta-\mathrm{T} 3)$ in B1 exceeded that in $\mathrm{O}$, in which the $\alpha$-T3 homologue predominated in both B1 $(1.7 \mathrm{mg} / 100 \mathrm{~g})$ and O1 $(1.4 \mathrm{mg} / 100 \mathrm{~g})$. When studying 12 oat genotypes and 30 barley genotypes grown in three different locations in the USA, Peterson and Qureshi (1993) showed that the content of tocochromanols ranged from 19 to $30 \mathrm{mg} / \mathrm{kg}$ for oats and from 42 to $80 \mathrm{mg} / \mathrm{kg}$ for barley. The oat samples predominantly contained $\alpha$-tocotrienol and $\alpha$-tocopherol, with lesser amounts of $\beta-T, \gamma-T$ and $\delta$-T3. Similarly, in barley $\alpha$-tocotrienol was the major fraction, followed by $\alpha$-tocopherol. However, barley also contained substantial quantities of $\beta$ - and $\gamma$-tocotrienols (Gangopadhyay et al., 2015; Peterson and Qureshi, 1993). It was observed that the investigated $\mathrm{W} 1, \mathrm{~B} 1$ and $\mathrm{O} 1$ grains are characterized by higher contents of tocotrienols than 
Nogala-Kałucka, M., Kawka, A., Dwiecki, K., Siger, A. (2020). Evaluation of bioactive compounds in cereals. Study of wheat, barley, oat and selected grain products. Acta Sci. Pol. Technol. Aliment., 19(4), 405-423. http://dx.doi.org/10.17306/J.AFS.2020.0858

Table 5. The content of total phenolic compounds in the methanol extracts and antioxidant activity of commercial cereal raw materials

\begin{tabular}{lcc}
\hline \multicolumn{1}{c}{ Sample } & $\begin{array}{c}\text { Total phenolic } \\
\text { compounds } \\
\text { mg/100 g d.m. }\end{array}$ & $\begin{array}{c}\text { Antioxidant } \\
\text { activity TRAP } \\
\text { mmol Trolox } / \mathrm{kg}\end{array}$ \\
\hline Wheat (W) & \\
\hline Hulled (W1) & $74.39 \pm 0.37^{\mathrm{f}}$ & $2.11 \pm 0.05^{\mathrm{e}, \mathrm{f}, \mathrm{g}}$ \\
Dehulled (W2) & $68.98 \pm 2.26^{\mathrm{e}}$ & $1.70 \pm 0.13^{\mathrm{c}}$ \\
Middlings (W3) & $56.78 \pm 0.44^{\mathrm{c}, \mathrm{d}}$ & $1.42 \pm 0.07^{\mathrm{b}}$ \\
Whole flour (W4) & $56.87 \pm 0.59^{\mathrm{c}, \mathrm{d}}$ & $1.86 \pm 0.02^{\mathrm{c}, \mathrm{d}}$ \\
Flour type 550 (W5) & $37.18 \pm 0.59^{\mathrm{a}}$ & $0.74 \pm 0.11^{\mathrm{a}}$ \\
\hline & Barley (B) & \\
\hline Hulled (B1) & $92.82 \pm 0.64^{\mathrm{h}}$ & $4.02 \pm 0.07^{\mathrm{k}}$ \\
Dehulled (B2) & $58.98 \pm 0.81^{\mathrm{d}, \mathrm{e}}$ & $1.99 \pm 0.01^{\mathrm{d}, \mathrm{e}, \mathrm{f}}$ \\
Middlings (B3) & $60.88 \pm 0.43^{\mathrm{d}}$ & $2.21 \pm 0.14^{\mathrm{f}, \mathrm{g}}$ \\
Whole flour (B4) & $74.90 \pm 2.86^{\mathrm{f}}$ & $2.16 \pm 0.05^{\mathrm{f}, \mathrm{g}}$ \\
\hline & Oat (O) & \\
\hline Hulled (O1) & $82.50 \pm 1.38^{\mathrm{g}}$ & $3.10 \pm 0.02^{\mathrm{j}}$ \\
Dehulled (O2) & $45.80 \pm 0.41^{\mathrm{b}}$ & $2.28 \pm 0.02^{\mathrm{g}}$ \\
Middlings (O3) & $53.82 \pm 0.34^{\mathrm{c}}$ & $1.93 \pm 0.04^{\mathrm{d}, \mathrm{e}}$ \\
\hline Whole flour (O4) & $43.08 \pm 2.42^{\mathrm{b}}$ & $2.84 \pm 0.07^{\mathrm{i}}$ \\
\hline & $53.06 \pm 1.06^{\mathrm{c}}$ & $2.56 \pm 0.09^{\mathrm{h}}$ \\
\hline
\end{tabular}

Values (means $\pm \mathrm{SD}, n=3$ ) bearing different superscripts are statistically significantly different $(P<0.05)$.

Total phenolic compounds related to gallic acid.

tocopherols, which is in agreement with the results reported by other authors (Idehen et al., 2017; Zieliński, 2008). The total tocochromanol content (Table 4) was the highest in $\mathrm{W} 1(4.6 \mathrm{mg} / 100 \mathrm{~g})$, considerable in B1 $(3.9 \mathrm{mg} / 100 \mathrm{~g})$ and the lowest in $\mathrm{O} 1(2.2 \mathrm{mg} / 100 \mathrm{~g})$. The decreased content of tocochromanols in oat grain is probably related to the preliminary hydrothermal treatment of unprocessed grain. Due to the high lipid contents in oat grains, unprocessed oat is subjected to a heat treatment to protect against rancidity developing in oat grain and its products during storage (van den Broeck et al., 2015). It needs to be stressed here that oats contain a phytase enzyme with enzymatic activity similar to that of wheat phytase. However, during heat treatment naturally occurring enzymes, including phytase, will be totally inactivated (Frølich et al., 1988; Frølich et al., 2013). Therefore, in the course of oat grain hydrothermal treatment, the lipolytic enzymes are inactivated along with phytases that are naturally found in the kernels. Furthermore, thermal processes affect the concentration of tocochromanols in the grain, with tocotrienols being more resistant to hydrothermal treatment than tocopherols (van den Broeck et al., 2015; Zieliński, 2008). Zielinski et al. (2013) showed that thermal treatment (extrusion) of cereal grains results in a significant decrease in tocopherol and tocotrienol contents, with $\alpha$-T and $\alpha$-T3 being the least resistant. The authors showed that the extrusion process increases the ratio of tocotrienols to tocopherols (-T3/-T), which is important in the regulation of the metabolism. In turn, Wrigley et al. (2017) reported that the - T3/-T ratio is proposed as a criterion for bioactivity of grain as a source of vitamin $\mathrm{E}$. Dehulled W2, B2 and O2 grains were characterized by a varied content of tocochromanols. Dehulling of $\mathrm{W} 2, \mathrm{~B} 2$ and $\mathrm{O} 2$ grain significantly decreased the total tocochromanol content by 13.61 and $8 \%$, respectively, in relation to the original grain (Table 4). In dehulled $\mathrm{W} 2, \mathrm{~B} 2$ and $\mathrm{O} 2$ grains the $\alpha-\mathrm{T}$ content decreased by approximately $25.8,72.9$ and $5.8 \%$, respectively, as compared to $\mathrm{W} 1, \mathrm{~B} 1$ and $\mathrm{O} 1$. The reduction in the amount of $\alpha$-T in sample B1 after dehulling is probably the result of husk removal, as well as the loss of $10-15 \%$ of embryos rich in this compound. It is worth noting that the barley husk contains considerable amounts of tocochromanols, similar to that in rice husks, while the oat hull contains trace amounts of the $\alpha$-T and $\alpha$-T3 homologues (Peterson, 1994).

In the W3, W4 and W5 wheat products obtained from processed dehulled grain W2, the total content of tocochromanols was $3.8,4.2$ and $2.4 \mathrm{mg} / 100 \mathrm{~g}$, respectively (Table 4). The W4 sample, in comparison to $\mathrm{W} 3$, contained more tocotrienols, including $\beta$-T3. Also, the share of tocotrienols in the total tocochromanol content was higher in W4 (76.3\%) than W3 (73.9\%), while the tocopherol contents were similar in both samples. Sample W5 (the so-called white refined flour), obtained during the multi-stage milling of $\mathrm{W} 2$ grain, contained $0.33 \mathrm{mg} / 100 \mathrm{~g}$ of tocopherols and $2.02 \mathrm{mg} / 100 \mathrm{~g}$ of tocotrienols, which constituted $86 \%$ 
Nogala-Kałucka, M., Kawka, A., Dwiecki, K., Siger, A. (2020). Evaluation of bioactive compounds in cereals. Study of wheat, barley, oat and selected grain products. Acta Sci. Pol. Technol. Aliment., 19(4), 405-423. http://dx.doi.org/10.17306/J.AFS.2020.0858

Table 6. The content of phenolic acids (after acid hydrolysis) in commercial cereal raw materials

\begin{tabular}{|c|c|c|c|c|c|c|c|}
\hline \multirow{2}{*}{ Sample } & \multicolumn{7}{|c|}{ Phenolic acids content, $\mathrm{mg} / 100 \mathrm{~g}$ d.m. } \\
\hline & protocatechuic & $\begin{array}{l}p \text {-hydrox- } \\
\text {-benzoesic }\end{array}$ & vanilic & $p$-coumaric & ferulic & sinapic & total \\
\hline \multicolumn{8}{|c|}{ Wheat (W) } \\
\hline Hulled (W1) & $0.35 \pm 0.05^{\mathrm{d}}$ & $3.45 \pm 0.07^{\mathrm{f}}$ & $0.44 \pm 0.07^{\mathrm{d}, \mathrm{e}}$ & $0.25 \pm 0.05^{\mathrm{a}, \mathrm{b}}$ & $6.58 \pm 0.08^{\mathrm{h}}$ & $1.01 \pm 0.09^{\mathrm{e}}$ & $12.08 \pm 0.08^{\mathrm{k}}$ \\
\hline Dehulled (W2) & $0.14 \pm 0.06^{\mathrm{a}, \mathrm{b}}$ & $5.25 \pm 0.05^{\mathrm{h}}$ & $0.23 \pm 0.05^{\mathrm{b}}$ & $0.39 \pm 0.06^{\mathrm{b}}$ & $1.57 \pm 0.06^{\mathrm{b}, \mathrm{c}}$ & $0.24 \pm 0.06^{\mathrm{a}, \mathrm{b}}$ & $7.82 \pm 0.06^{\mathrm{h}}$ \\
\hline Middlings (W3) & $0.11 \pm 0.05^{\mathrm{a}, \mathrm{b}}$ & $5.08 \pm 0.06^{\mathrm{g}}$ & $0.24 \pm 0.01^{\mathrm{b}}$ & $0.23 \pm 0.08^{\mathrm{a}, \mathrm{b}}$ & $2.69 \pm 0.04^{\mathrm{f}}$ & $0.50 \pm 0.04^{\mathrm{d}}$ & $8.85 \pm 0.05^{\mathrm{i}}$ \\
\hline Whole flour (W4) & $0.53 \pm 0.08^{\mathrm{e}}$ & $6.46 \pm 0.09^{\mathrm{i}}$ & $0.25 \pm 0.03^{\mathrm{b}, \mathrm{c}}$ & $0.15 \pm 0.04^{\mathrm{a}}$ & $4.15 \pm 0.02^{\mathrm{g}}$ & $0.23 \pm 0.02^{\mathrm{a}, \mathrm{b}}$ & $11.77 \pm 0.09^{\mathrm{j}}$ \\
\hline Flour type $550(\mathrm{~W} 5)$ & $0.07 \pm 0.04^{\mathrm{a}}$ & $1.30 \pm 0.04^{\mathrm{d}}$ & $0.07 \pm 0.05^{\mathrm{a}}$ & $0.18 \pm 0.02^{\mathrm{a}}$ & $1.02 \pm 0.08^{\mathrm{a}}$ & $0.10 \pm 0.05^{\mathrm{a}}$ & $2.74 \pm 0.04^{\mathrm{a}}$ \\
\hline \multicolumn{8}{|c|}{ Barley (B) } \\
\hline Hulled (B1) & $0.31 \pm 0.04^{\mathrm{c}, \mathrm{d}}$ & $0.97 \pm 0.04^{\mathrm{a}, \mathrm{b}}$ & $0.83 \pm 0.05^{\mathrm{g}}$ & $0.16 \pm 0.03^{\mathrm{a}}$ & $2.53 \pm 0.05^{\mathrm{e}}$ & 0.00 & $4.79 \pm 0.07^{\mathrm{f}}$ \\
\hline Dehulled (B2) & $0.35 \pm 0.05^{\mathrm{d}}$ & $0.82 \pm 0.05^{\mathrm{a}}$ & $0.26 \pm 0.06^{\mathrm{b}, \mathrm{c}}$ & $0.21 \pm 0.01^{\mathrm{a}}$ & $2.26 \pm 0.03^{\mathrm{d}}$ & 0.00 & $3.91 \pm 0.05^{\mathrm{d}}$ \\
\hline Middlings (B3) & $0.23 \pm 0.08^{\mathrm{a}, \mathrm{b}, \mathrm{c}, \mathrm{d}}$ & $0.90 \pm 0.06^{\mathrm{a}}$ & $0.10 \pm 0.03^{\mathrm{a}}$ & $0.14 \pm 0.07^{\mathrm{a}}$ & $2.22 \pm 0.04^{\mathrm{d}}$ & 0.00 & $3.59 \pm 0.03^{\mathrm{c}}$ \\
\hline Whole flour (B4) & $0.21 \pm 0.07^{\mathrm{a}, \mathrm{b}, \mathrm{c}, \mathrm{d}}$ & $2.59 \pm 0.04^{\mathrm{e}}$ & $0.45 \pm 0.02^{\mathrm{d}, \mathrm{e}}$ & $0.39 \pm 0.06^{\mathrm{b}}$ & $2.51 \pm 0.01^{\mathrm{e}}$ & $0.96 \pm 0.04^{\mathrm{e}}$ & $7.10 \pm 0.01^{\mathrm{g}}$ \\
\hline \multicolumn{8}{|c|}{ Oat $(\mathrm{O})$} \\
\hline Hulled (O1) & $0.16 \pm 0.04^{\mathrm{a}, \mathrm{b}, \mathrm{c}}$ & $0.98 \pm 0.04^{\mathrm{a}, \mathrm{b}}$ & $0.47 \pm 0.04^{\mathrm{d}, \mathrm{e}}$ & $0.12 \pm 0.06^{\mathrm{a}}$ & $1.49 \pm 0.06^{\mathrm{b}}$ & $0.32 \pm 0.08^{b, c}$ & $3.54 \pm 0.07^{\mathrm{b}, \mathrm{c}}$ \\
\hline Dehulled (O2) & $0.14 \pm 0.05^{\mathrm{a}, \mathrm{b}}$ & $0.95 \pm 0.07^{\mathrm{a}, \mathrm{b}}$ & $0.49 \pm 0.02^{\mathrm{e}}$ & $0.17 \pm 0.05^{\mathrm{a}}$ & $1.55 \pm 0.05^{\mathrm{b}, \mathrm{c}}$ & $0.29 \pm 0.06^{\mathrm{b}, \mathrm{c}}$ & $3.58 \pm 0.09^{\mathrm{c}}$ \\
\hline Middlings (O3) & $0.27 \pm 0.06^{\mathrm{b}, \mathrm{c}, \mathrm{d}}$ & $1.15 \pm 0.02^{\mathrm{c}, \mathrm{d}}$ & $0.05 \pm 0.02^{\mathrm{a}}$ & $0.19 \pm 0.05^{\mathrm{a}}$ & $1.46 \pm 0.04^{\mathrm{b}}$ & $0.26 \pm 0.04^{\mathrm{a}, \mathrm{b}}$ & $3.39 \pm 0.05^{\mathrm{b}}$ \\
\hline Whole flour (O4) & $0.27 \pm 0.02^{\mathrm{b}, \mathrm{c}, \mathrm{d}}$ & $1.09 \pm 0.06^{\mathrm{b}, \mathrm{c}}$ & $0.36 \pm 0.01^{\mathrm{c}, \mathrm{d}}$ & $0.10 \pm 0.08^{\mathrm{a}}$ & $1.45 \pm 0.02^{\mathrm{b}}$ & $0.30 \pm 0.07^{\mathrm{b}, \mathrm{c}}$ & $3.57 \pm 0.08^{\mathrm{b}, \mathrm{c}}$ \\
\hline Bran (O5) & $0.22 \pm 0.03^{\mathrm{a}, \mathrm{b}, \mathrm{c}, \mathrm{d}}$ & $1.15 \pm 0.04^{\mathrm{c}, \mathrm{d}}$ & $0.61 \pm 0.03^{\mathrm{f}}$ & $0.18 \pm 0.09^{\mathrm{a}}$ & $1.66 \pm 0.06^{\mathrm{c}}$ & $0.46 \pm 0.05^{\mathrm{c}, \mathrm{d}}$ & $4.27 \pm 0.07^{\mathrm{e}}$ \\
\hline
\end{tabular}

Values (means $\pm \mathrm{SD}, n=3$ ) bearing different superscripts are statistically significantly different $(P<0.05)$. Values (means $\pm \mathrm{SD}$, $n=3$ ) related to gallic acid.

of the total tocochromanol content (2.35\%), with $\beta$-T3 being the main tocotrienol. The level of tocopherols in W5 was 3-fold lower than in the W3 and W4 products or the W2 grain. In white refined flours the amount of bioactive compounds is significantly reduced during grain milling. This is due to the total or partial removal of the bran and/or germ fractions (Fardet, 2010; Heshe et al., 2016).

Barley products $\mathrm{B} 3$ and $\mathrm{B} 4$, obtained by processing of B2 grain, contained $\alpha-T, \beta-T$ and trace amounts of $\delta$-T, while from the tocotrienol group it was $\alpha$-T3 and
$\beta$-T3 (Table 4). The total content of tocochromanols in B3 and B4 was higher by 25 and $42 \%$, respectively, than in B2. Both samples contained greater amounts of tocotrienols than tocopherols. Sample B4, unlike B3, was characterized by higher contents of tocotrienols, mainly $\alpha-\mathrm{T} 3$. However, the share of tocotrienols in the total pool of tocochromanols was slightly higher in B4 (71\%) than B3 (70\%). In both samples small differences were observed in the amount of tocopherols, with a greater amount of $\alpha-\mathrm{T}$ found in B4. 
Oat products $\mathrm{O} 3, \mathrm{O} 4$ and $\mathrm{O}$, obtained during processing of $\mathrm{O} 2$ grain, contained the $\alpha$-T homologue from the tocopherols group as well as $\alpha-\mathrm{T} 3$ and $\beta$-T3 from the tocotrienol group. The total content of tocochromanols in $\mathrm{O} 3, \mathrm{O} 4$ and $\mathrm{O} 5$ was comparable, but slightly lower than in dehulled grain $\mathrm{O} 2$. In $\mathrm{O} 3$ and O4, tocotrienols accounted for 76.8 and $74.7 \%$, respectively, of the total tocochromanol amount. It was noted that the share of tocotrienols in total tocochromanols was higher in O5 (85\%) than in the other oat samples tested. The content of vitamin $\mathrm{E}$ in the oat grains and the resulting processed products seems to be lower than in the other studied commercial raw materials. The content of selected bioactive components varied greatly between the three whole cereal grains as well as the obtained products, as presented in Tables 5 and 6 .

The contents of total phenolic compounds in the analyzed samples are presented in Table 5. The highest level of phenolic compounds in the wheat samples was recorded in non-hulled grain (W1 $-74.4 \mathrm{mg} / 100 \mathrm{~g}$ d.m.). Some phenolic compounds were lost during husk removal (W2 - $70.0 \mathrm{mg} / 100 \mathrm{~g}$ d.m. in dehulled grains). Lower levels of those substances were detected in ground wheat grain (W3 $-56.8 \mathrm{mg} / 100 \mathrm{~g} \mathrm{d.m}$.). The content of phenolics in white refined wheat flour (W5) was lower than in dehulled grains. Additionally, it was noted that wholemeal flour (W4) contained about $50 \%$ more phenolic compounds than wheat flour type 550 (W5). Hulled barley grain (B1) contained $92.8 \mathrm{mg} / 100 \mathrm{~g}$ d.m. of phenolic compounds (Table 5). As in the case of wheat, a decrease in phenolic contents was observed after husk removal, with similar levels of those substances also recorded in ground barley grain (B3 - $60.9 \mathrm{mg} / 100 \mathrm{~g} \mathrm{~d} . \mathrm{m})$. Wholemeal barley flour (B4) retained a relatively high level of polyphenols (about $80 \%$ of those substances present in hulled barley grain). Losses of phenolic compounds (about $45 \%$ ) as a result of dehulling were also observed in the case of oat grains. The concentration of polyphenols in ground oat grain (O3) and oat bran (O5) was about $53 \mathrm{mg} / 100 \mathrm{~g}$ d.m. The lowest content of phenolic compounds (among the tested oat products) was recorded in wholemeal oat flour (O4; $43.1 \mathrm{mg} / 100 \mathrm{~g}$ d.m.).

Apart from total phenolic compounds, the content of phenolic acids was also determined in grains of wheat, barley and oat as well as their products (Table
6). Wheat and its products turned out to be the richest sources of phenolic acids (from $12.08 \mathrm{mg} / 100 \mathrm{~g}$ d.m. in non hulled grains (W1) to $2.74 \mathrm{mg} / 100 \mathrm{~g}$ d.m. in white refined wheat flour (W5) wheat flour type 550). The dominant acids in wheat and its products were $p$-hydroxybenzoic (from $5.25 \mathrm{mg} / 100 \mathrm{~g}$ d.m. in W2 to $1.30 \mathrm{mg} / 100 \mathrm{~g}$ d.m. in W5) and ferulic acids (from $6.58 \mathrm{mg} / 100 \mathrm{~g}$ d.m. in $\mathrm{W} 1$ to $1.02 \mathrm{mg} / 100 \mathrm{~g} \mathrm{~d} . \mathrm{m}$. in W5). Ferulic acid was the main phenolic acid in barley (from $2.53 \mathrm{mg} / 100 \mathrm{~g} \mathrm{~d} . \mathrm{m}$. in B1 to $2.22 \mathrm{mg} / 100 \mathrm{~g}$ d.m. in B3). Surprisingly, the content of total phenolic acids in wholemeal barley flour (B4; $7.10 \mathrm{mg} / 100 \mathrm{~g}$ d.m.) was higher than in hulled grains $(4.79 \mathrm{mg} / 100 \mathrm{~g}$ d.m.). This may be a result of the release of bound phenolic acids from the kernel tissue while the grain is ground into flour. In whole cereal grains a majority of polyphenols are tightly bound to the cell walls within the grain matrix. Free phenolic acids are found in the outer layer of the pericarp. Bound phenolic acids are esterified to the cell walls (Gani et al., 2012). Oat contains the highest levels of free, or unbound, phenolics (up to $30 \%$ of total phenolics), whereas wheat, barley and rye contain only very low levels (as little as 1.6\%; Belobrajdic and Bird, 2013b). Also, in the case of oat, ferulic acid was the dominant phenolic acid (1.49 $\mathrm{mg} / 100 \mathrm{~g}$ d.m. in hulled grains - O1). The total phenolic acid content (Table 6) was higher in oat bran $\mathrm{O} 5$ $(4.27 \mathrm{mg} / 100 \mathrm{~g} \mathrm{~d} . \mathrm{m}$.) in comparison to grains and other oat products (3.54-3.58 mg/100 g d.m.). As in the case of barley, bound phenolic acids may be released during technological processes. The relatively high content of ferulic acid in whole cereal grains has been confirmed by other authors. According to Belobrajdic and Bird (2013b), the concentration of this polyphenol in wheat, barley and oat is $16-213 \mathrm{mg} / 100 \mathrm{~g}, 110-120$ $\mathrm{mg} / 100 \mathrm{~g}$ and $2.1-2.4 \mathrm{mg} / 100 \mathrm{~g}$, respectively.

The Total Radical Trapping Antioxidant Potential (TRAP) of the analyzed grains and their products was also determined (Table 5). TRAP is a measure of the antioxidant capacity of the sample. The TRAP value was the highest in the case of barley grains and their products (1.99-4.02 mmol Trolox $/ \mathrm{kg}$ ) and the lowest for wheat samples $(0.74-2.11 \mathrm{mmol}$ Trolox $/ \mathrm{kg})$. In wheat and barley grains and their products, a positive correlation was found between TRAP values and total phenolic contents. This is consistent with the fact that in cereals (especially whole grains) antioxidant 
Nogala-Kałucka, M., Kawka, A., Dwiecki, K., Siger, A. (2020). Evaluation of bioactive compounds in cereals. Study of wheat, barley, oat and selected grain products. Acta Sci. Pol. Technol. Aliment., 19(4), 405-423. http://dx.doi.org/10.17306/J.AFS.2020.0858
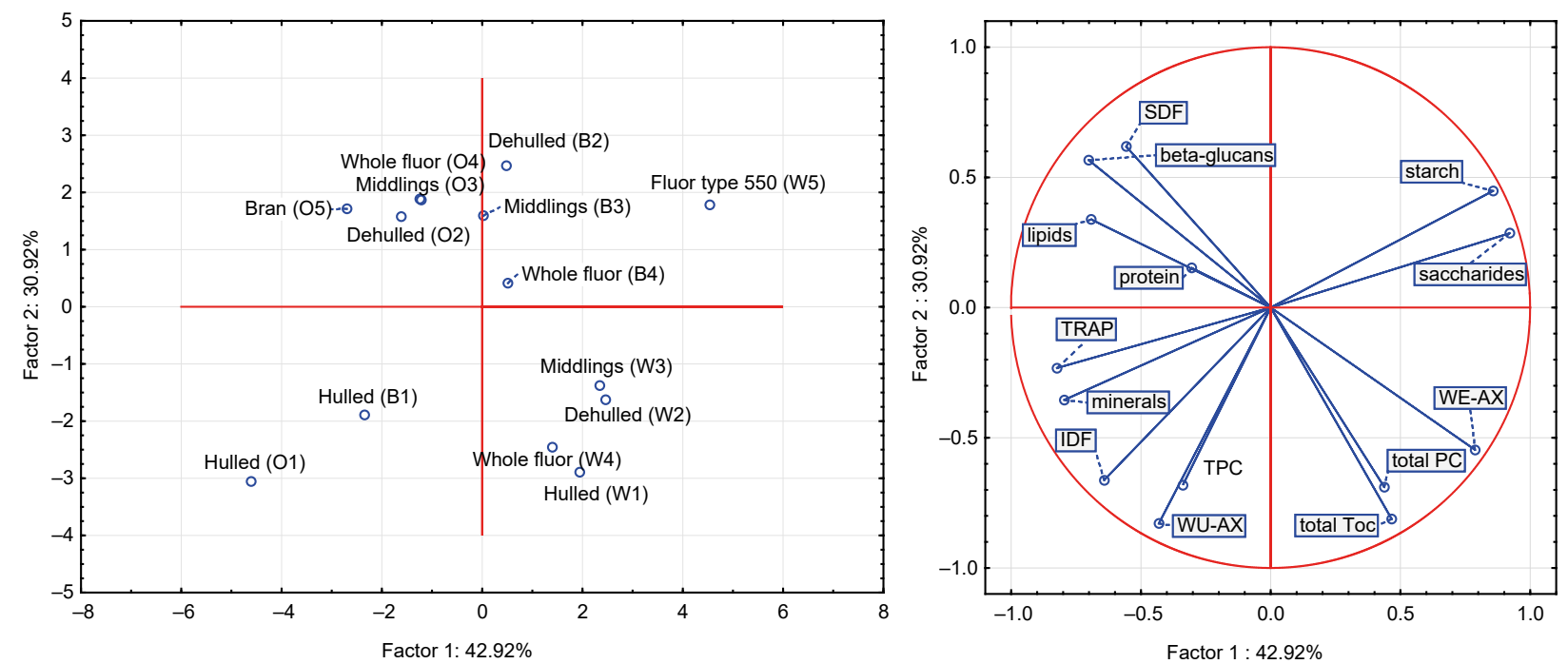

Fig. 1. Distribution of study samples based on the principal component analysis

ability is mainly related to the contents of phenolic compounds (Belobrajdic and Bird, 2013b). However, no such correlation was noticed in the case of oat and its products (TRAP at 1.93-3.10 mmol Trolox $/ \mathrm{kg}$ ). This may be connected with the ability to scavenge free radicals by other substances present in grains e.g. proteins (Elias et al., 2008).

The results of the Principal Component Analysis (PCA) showed that the plane defined by the first two principal components explains $73.8 \%$ of the information in the original data (Fig. 1). Factor 1 is positively correlated with the content of saccharides $(r=0.921)$, $\operatorname{starch}(r=0.857)$ and WE-AX $(r=0.788)$, while it is negatively correlated with TRAP $(r=-0.823)$, as well as the contents of minerals $(r=-0.795), \beta$-glucan $(r=-0.701)$ and lipids $(r=-0.691)$. Factor 2 is positively correlated with $\mathrm{SDF}(r=0.618)$ and $\beta$-glucan $(r=-0.813)$, while being negatively correlated with WU-AX $(r=-0.829)$ and total tocopherols $(r=$ $-0.921)$. This analysis differentiates all the investigated cereal grains (wheat, barley, oat) and their products. It may be observed here that wheat products differ in the contents of individual components, since they are characterized by high contents of tocochromanols and phenolic compounds as well as WE-AX (except for refined wheat flour, which is mainly a source of saccharides). In the case of barley and oat products, the analysis shows no differences between these product groups. It was also shown that dehulling of barley and oat grain causes statistically significant differences in the content of nutrients and natural antioxidants (Fig. 1).

\section{CONCLUSION}

The assessment of selected quality parameters (total impurities, uniformity, test weight, 1000 kernel weight and falling number) of unprocessed commercial wheat, barley and oat grain indicates their good technological quality and processability. Dehulling of wheat, barley and oat grain significantly reduced their levels of minerals, protein and total dietary fiber (TDF), except for the amount of protein in dehulled wheat and oat grain. Furthermore, the contents of saccharides, total starch and lipids increased, but only in dehulled wheat and oat grain. Nutrients are distributed relatively uniformly in the oat kernel, thus there are no major differences in the chemical composition between the raw material (dehulled oat grain) and oat products (ground grain, wholemeal flour). The commercial cereal raw materials studied are characterized by a different chemical composition. Thus, the type of cereal grain and the method of its processing have a significant impact on the nutrient contents in cereal products. Oat bran, in 
contrast to other oat products, was characterized by the highest content of minerals, protein and TDF, at the smallest amounts of saccharides and total starch. The lowest content of minerals was recorded in wheat flour type 550 .

Among the components of the total dietary fiber (TDF), the lowest amount of the insoluble (IDF) and soluble (SDF) fractions were found in hulled wheat, while they were highest in hulled oat. Hulled barley and oat were the richest sources of SDF, as a valuable ingredient from a nutritional point of view. Dehulling of wheat, barley and oat grain significantly reduced the contents of dietary fiber and its components in dehulled grains. Additionally, dehulled grains contain significantly lower amounts of water-extractable arabinoxylans compared to water-unextractable arabinoxylans. Dehulled barley and oat grain contain more SDF and $\beta$-glucans, i.e. nutrients valuable from a nutritional point of view, at lower total arabinoxylan levels.

The observed decreased content of tocochromanols in oat grain is probably related to the preliminary hydrothermal treatment of unprocessed grain. Due to the high lipid contents in oat grain, unprocessed oat is subjected to heat treatment to prevent rancidity in grain and oat products during storage. Furthermore, thermal processes affect the concentration of tocochromanols in the grain, with tocotrienols being more resistant to hydrothermal treatment than tocopherols. Grain dehulling also significantly reduced the total amount of tocochromanols in relation to the original grain.

A decrease in the content of phenolic compounds was observed during grain husk removal. Lower levels of these substances were recorded in ground wheat grain. The content of phenolics in refined wheat flour was lower than in dehulled grain. Additionally, it was noted that wholemeal flour contained about $50 \%$ more phenolic compounds than wheat flour type 550 . Wholemeal barley flour retained a relatively high level of polyphenols (about $80 \%$ of those substances present in hulled barley grain). The lowest phenolic content among oat products was recorded in wholemeal oat flour. Wheat grain and its products turned out to be the richest sources of phenolic acids, mainly $p$-hydroxybenzoic and ferulic acids. The latter was the main phenolic acid in barley. Surprisingly the determined content of total phenolic acids in wholemeal barley flour was higher than in hulled grain. This may be due to the release of bound phenolic acids from the grain tissue during milling. In whole cereal grain the majority of polyphenols are tightly bound to the cell walls within the grain matrix. Free phenolic acids are found in the outer layer of the pericarp. Bound phenolic acids are esterified to the cell wall. Oat contains the highest levels of free, or unbound, phenolics (up to $30 \%$ of total phenolics), whereas wheat, barley and rye contain only very low levels (as little as $1.6 \%$ ). Also, in the case of oat, ferulic acid was the dominant phenolic acid. As in the case of barley, bound phenolic acids may be released during technological processes. The TRAP value (a measure of the antioxidant capacity) was the highest in the case of barley grain and products, while it was lowest for the wheat samples. In barley and wheat grain, as well as in their products, a positive correlation was found between TRAP values and total phenolic contents. This is consistent with the fact that in cereals (especially whole grains) the antioxidant ability is mainly associated with phenolic compounds. However, in the case of oat and its products no such correlation was observed. This may be connected with the ability of other substances present in grain, e.g. proteins, to scavenge free radicals. The PCA results indicate that wheat products differ in the contents of individual components. They are characterized by high contents of tocochromanols, phenolic compounds and water-extractable arabinoxylans, with the exception of white refined wheat flour, which is mainly a source of saccharides. In the case of barley and oat products, the analysis showed no differences between these product groups. It was also shown that dehulling of barley and oat grain causes statistically significant differences in the contents of nutrients and natural antioxidants.

\section{REFERENCES}

AACC method 76-13.01 (n.d.). Total starch assay procedure (megazyme amyloglucosidase/alpha-amylase method). In AACC approved methods of analysis (11th ed.). Cereals and Grains Association.

Asp, N. G., Johansson, C. G., Hallmer, H., Siljestroem, M. (1983). Rapid enzymic assay of insoluble and soluble dietary fiber. J. Agric. Food Chem., 31(3), 476-482. https://doi.org/10.1021/jf00117a003 
Nogala-Kałucka, M., Kawka, A., Dwiecki, K., Siger, A. (2020). Evaluation of bioactive compounds in cereals. Study of wheat, barley, oat and selected grain products. Acta Sci. Pol. Technol. Aliment., 19(4), 405-423. http://dx.doi.org/10.17306/J.AFS.2020.0858

Baik, B.-K., Ullrich, S. E. (2008). Barley for food: Characteristics, improvement, and renewed interest. J. Cereal Sci., 48(2), 233-242. https://doi.org/10.1016/j.jcs.2008. 02.002

Belobrajdic, D. P., Bird, A. R. (2013a). The potential role of phytochemicals in wholegrain cereals for the prevention of type-2 diabetes. Nutr. J., 12(1), 62. https://doi. org/10.1186/1475-2891-12-62

Belobrajdic, D. P., Bird, A. R. (2013b). The potential role of phytochemicals in wholegrain cereals for the prevention of type-2 diabetes. Nutr. J., 12(1), 62. https://doi. org/10.1186/1475-2891-12-62

Boros, D., Gołębiewska, K., Gołębiewski, D., Paczkowska, O., Wiśniewska, M., Fraś, A. (2015). Wartość odżywcza i właściwości prozdrowotne ziarna odmian zbóż i nasion rzepaku zalecanych do uprawy w Polsce. Instytut Hodowli i Aklimatyzacji Roślin - Państwowy Instytut Badawczy.

Butt, M. S., Tahir-Nadeem, M., Khan, M. K. I., Shabir, R., Butt, M. S. (2008). Oat: unique among the cereals. Eur. J. Nutr., 47(2), 68-79. https://doi.org/10.1007/s00394008-0698-7

Doehlert, D. C., Moore, W. R. (1997). Composition of oat bran and flour prepared by three different mechanisms of dry milling. Cereal Chem. J., 74(4), 403-406. https:// doi.org/10.1094/CCHEM.1997.74.4.403

Elias, R. J., Kellerby, S. S., Decker, E. A. (2008). Antioxidant activity of proteins and peptides. Crit. Rev. Food Sci. Nutr., 48(5), 430-441. https://doi. org/10.1080/10408390701425615

Fardet, A. (2010). New hypotheses for the health-protective mechanisms of whole-grain cereals: what is beyond fibre? Nutr. Res. Rev., 23(1), 65-134. https://doi. org/10.1017/S0954422410000041

Frank, J., Chin, X. W. D., Schrader, C., Eckert, G. P., Rimbach, G. (2012). Do tocotrienols have potential as neuroprotective dietary factors? Ageing Res. Rev., 11(1), 163-180. https://doi.org/10.1016/j.arr.2011.06.006

Frølich, W., Wahlgren, M., Drakenberg, T. (1988). Studies on phytase activity in oats and wheat using ${ }^{31} \mathrm{P}-\mathrm{NMR}$ spectroscopy. J. Cereal Sci., 8(1), 47-53. https://doi. org/10.1016/S0733-5210(88)80048-1

Frølich, W., Åman, P., Tetens, I. (2013). Whole grain foods and health - a Scandinavian perspective. Food Nutr. Res., 57(1), 18503. https://doi.org/10.3402/fnr. v57i0.18503

Gangopadhyay, N., Hossain, M., Rai, D., Brunton, N. (2015). A review of extraction and analysis of bioactives in oat and barley and scope for use of novel food processing technologies. Molecules, 20(6), 10884-10909. https:// doi.org/10.3390/molecules200610884

Gani, A., Sm, W., Fa, M. (2012). Whole-grain cereal bioactive compounds and their health benefits: A review. J. Food Proc. Technol., 3(3). https://doi.org/10.4172/21577110.1000146

Gąsiorowski, H., Abdalla, M. (2004). Pszenica: chemia i technologia. Warszawa: PWRiL.

Gawęcki, J., Obuchowski, W. (2016). Produkty zbożowe: technologia i rola w żywieniu człowieka. Poznań: Wydawnictwo Uniwersytetu Przyrodniczego.

Gil, A., Ruiz-Lopez, M. D., Fernandez-Gonzalez, M., Martinez de Victoria, E. (2014). The FINUT healthy lifestyles guide: Beyond the food pyramid ${ }^{1-3}$. Adv. Nutr., 5(3), 358S-367S. https://doi.org/10.3945/an.113.005637

Grzesiuk, S. (1988). Biologia ziarniaków zbóż. Warszawa: PWN.

Hashimoto, S., Shogren, M. D., Pomeranz, Y. (1987). Cereal pentosans: Their estimation and significance. pentosans in wheat and milles wheat products. Cereal Chem., 64, 30-34.

Heleno, S. A., Martins, A., Queiroz, M. J. R. P., Ferreira, I. C. F. R. (2015). Bioactivity of phenolic acids: Metabolites versus parent compounds: A review. Food Chem., 173, 501-513. https://doi.org/10.1016/j.foodchem.2014. 10.057

Henry, R. J. (1985). A comparison of the non-starch carbohydrates in cereal grains. J. Sci. Food Agric., 36(12), 1243-1253. https://doi.org/10.1002/jsfa.2740361207

Heshe, G. G., Haki, G. D., Woldegiorgis, A. Z., Gemede, H. F. (2016). Effect of conventional milling on the nutritional value and antioxidant capacity of wheat types common in Ethiopia and a recovery attempt with bran supplementation in bread. Food Sci. Nutr., 4(4), 534-543. https://doi.org/10.1002/fsn3.315

Holtekjølen, A. K., Sahlstrøm, S., Knutsen, S. H. (2011). Phenolic contents and antioxidant activities in covered whole-grain flours of Norwegian barley varieties and in fractions obtained after pearling. Acta Agric. Scand., Sect. B - Soil Plant Sci., 61(1), 67-74. https://doi. org/10.1080/09064710903496527

ICC no. 103/1 (1972). Determination of besatz of rye. In ICC standard method. Vienna: International Association for Cereal Science and Technology.

ICC no. 104/1 (1990). Determination of ash in cereals and cereal products. In ICC standard method. Vienna: International Association for Cereal Science and Technology.

ICC no. 105/2 (1994). Determination of crude protein in cereals and cereal products for food and for feed. In ICC 
Nogala-Kałucka, M., Kawka, A., Dwiecki, K., Siger, A. (2020). Evaluation of bioactive compounds in cereals. Study of wheat, barley, oat and selected grain products. Acta Sci. Pol. Technol. Aliment., 19(4), 405-423. http://dx.doi.org/10.17306/J.AFS.2020.0858

standard method. Vienna: International Association for Cereal Science and Technology.

ICC no. 107/1 (1995). Determination of the "Falling Number" according to Hagberg-Perten as a measure of the degree of alpha-amylase activity in grain and flour. In ICC standard method. Vienna: International Association for Cereal Science and Technology.

ICC no. 110/1 (1976). Determination of the moisture content of cereals and cereal products (practical method). In ICC standard method. Vienna: International Association for Cereal Science and Technology.

ICC no. 166 (1998). Determination of ß-glucan in barley, oat and rye. In ICC standard method. Vienna: International Association for Cereal Science and Technology.

Idehen, E., Tang, Y., Sang, S. (2017). Bioactive phytochemicals in barley. J. Food Drug Anal., 25(1), 148-161. https://doi.org/10.1016/j.jfda.2016.08.002

Jankowski, S. (1988). Surowce mączne i kaszowe: ziarno zbóż, gryki i grochu. Warszawa: WN-T.

Kawka, A. (2004). Jęczmień i jego produkty: charakterystyka, otrzymywanie i wykorzystanie w żywieniu człowieka. Poznań: Wyd. AR.

Kawka, A., Matuszewska, A., Padlewska, A. (2014). Całoziarnowa mąka owsiana - surowiec do produkcji pieczywa prozdrowotnego. Bromat. Chem. Toksykol., 47(3), 480-485.

Kawka, A., Achremowicz, B. (2014). Owies - roślina XXI wieku. Wykorzystanie żywieniowe i przemysłowe. Nauka Przyr. Technol., 8(3), \#41. http://www.npt.up-poznan.net/tom8/zeszyt3/art_41.pdf

Khan, K. (2009). Wheat: Chemistry and technology. Elsevier Science.

Krejpcio, Z., Suliburska, J., Król, E., Kawka, A., Marcinek, K. (2015). Wpływ rodzaju ziarna zboża i stopnia jego przetworzenia na potencjalną biodostępność składników mineralnych w warunkach in vitro. Bromat. Chem. Toksykol., 48(1), 74-80.

Lachman, J., Musilová, J., Kotíková, Z., Hejtmánková, K., Orsák, M., Přribyl, J. (2012). Spring, einkorn and emmer wheat species - potential rich sources of free ferulic acid and other phenolic compounds. Plant Soil Environ., 58(8), 347-353. https://doi.org/10.17221/289/2012-PSE

Lamer-Zarawska, E., Oszmiański, J. (1998). Rola niektórych substancji roślinnych w profilaktyce przeciwnowotworowej. Wiad. Ziel., 40(5), 1-4.

Landberg, R., Marklund, M., Kamal-Eldin, A., Åman, P. (2014). An update on alkylresorcinols - Occurrence, bioavailability, bioactivity and utility as biomarkers. J. Funct. Foods, 7, 77-89. https://doi.org/10.1016/j. jff.2013.09.004
Liukkonen, K.-H., Katina, K., Wilhelmsson, A., Myllymaki, O., Lampi, A.-M., Kariluoto, S., ..., Poutanen, K. (2003). Process-induced changes on bioactive compounds in whole grain rye. Proc. Nutr. Soc., 62(1), 117-122. https:// doi.org/10.1079/PNS2002218

Lobo, V., Patil, A., Phatak, A., Chandra, N. (2010). Free radicals, antioxidants and functional foods: Impact on human health. Pharm. Rev., 4(8), 118. https://doi. org/10.4103/0973-7847.70902

Masisi, K., Beta, T., Moghadasian, M. H. (2016). Antioxidant properties of diverse cereal grains: A review on in vitro and in vivo studies. Food Chem., 196, 90-97. https://doi.org/10.1016/j.foodchem.2015.09.021

Mutwali, N. I. A., Mustafa, A. I., Gorafi, Y. S. A., Mohamed Ahmed, I. A. (2016). Effect of environment and genotypes on the physicochemical quality of the grains of newly developed wheat inbred lines. Food Sci. Nutr., 4(4), 508-520. https://doi.org/10.1002/fsn3.313

Ndolo, V. U., Beta, T. (2014). Comparative studies on composition and distribution of phenolic acids in cereal grain botanical fractions. Cereal Chem. J., 91(5), 522-530. https://doi.org/10.1094/CCHEM-10-13-0225-R

Newman, R. K., Newman, C. W. (2008). Barley for food and health. John Wiley. https://doi.org/10.1002/978047 0369333

Peterson, D., Qureshi, A. A. (1993). Genotype and environment effects on tocols of barley and oats'. Cereal Chem., $70(2), 157-162$.

Peterson, D. M. (1994). Barley tocols: effects of milling, malting, and mashing. Cereal Chem., 71(1), 42-44.

Piironen, V., Syvaoja, E. L., Varo, P., Salminen, K., Koivistoinen, P. (1986). Tocopherols and tocotrienols in cereal products from Finland. Cereal Chem., 63, 78-81.

PN EN ISO 520 (2011). Cereals and pulses - determination of the mass of 1000 grains. Polish Committee for Standardization.

PN-EN ISO 7971-3 (2019). Cereal grain - Determination of the mass-weight density, called hectolitre mass - Part 3: Routine method. Polish Committee for Standardization. https://infostore.saiglobal.com/en-us/Standards/ PN-EN-ISO-7971-3-2019-03-945942_SAIG_PKN PKN_2715894/

Ragaee, S., Guzar, I., Abdel-Aal, E.-S. M., Seetharaman, K. (2012). Bioactive components and antioxidant capacity of Ontario hard and soft wheat varieties. Can. J. Plant Sci., 92(1), 19-30. https://doi.org/10.4141/cjps2011-100

Rice-Evans, C., Miller, N., Paganga, G. (1997). Antioxidant properties of phenolic compounds. Trends Plant Sci., 2(4), 152-159. https://doi.org/10.1016/S1360-1385(97) $01018-2$ 
Nogala-Kałucka, M., Kawka, A., Dwiecki, K., Siger, A. (2020). Evaluation of bioactive compounds in cereals. Study of wheat, barley, oat and selected grain products. Acta Sci. Pol. Technol. Aliment., 19(4), 405-423. http://dx.doi.org/10.17306/J.AFS.2020.0858

Rokosik, E., Dwiecki, K., Siger, A. (2019). The quality of cold-pressed rapeseed oil obtained from seeds of Brassica napus L. with increased moisture content. Acta Sci. Pol. Technol. Alim., 18(2), 205-218. https://doi.org/ 10.17306/J.AFS.0672

Ryynänen, M., Lampi, A.-M., Salo-Väänänen, P., Ollilainen, V., Piironen, V. (2004). A small-scale sample preparation method with HPLC analysis for determination of tocopherols and tocotrienols in cereals. J. Food Comp. Anal., 17(6), 749-765. https://doi.org/10.1016/ j.jfca.2003.09.014

Schneider, C. (2005). Chemistry and biology of vitamin E. Molec. Nutr. Food Res., 49(1), 7-30. https://doi. org/10.1002/mnfr.200400049

Siger, A., Czubinski, J., Kachlicki, P., Dwiecki, K., Lampart-Szczapa, E., Nogala-Kalucka, M. (2012). Antioxidant activity and phenolic content in three lupin species. J. Food Comp. Anal., 25(2), 190-197. https://doi.org/ 10.1016/j.jfca.2011.10.002

Siger, A., Gawrysiak-Witulska, M., Wawrzyniak, J. (2018). Changes in contents of phenolic compounds (sinapic acid derivatives) in seeds of Brassica napus L. under adverse storage conditions. Acta Sci. Pol. Technol. Aliment., 17(4), 367-375. https://doi.org/10.17306/J.AFS.0596

van den Broeck, H., Londono, D., Timmer, R., Smulders, M., Gilissen, L., van der Meer, I. (2015). Profiling of nutritional and health-related compounds in oat varieties. Foods, 5(4), 2. https://doi.org/10.3390/foods5010002

Wrigley, C., Batey, I., Miskelly, D. (Eds.; 2017). Cereal grains: assessing and managing quality (2nd. ed.). Cambridge: Woodhead Publishing - Elsevier.

Zieliński, H., Achremowicz, B., Przygodzka, G. (2012). Przeciwutleniacze ziarniaków zbóż. Food Sci. Technol. Qual., 1(80), 5-26.

Zielinski, H., Ciska, E., Kozlowska, H. (2013). The cereal grains: focus on vitamin E. Czech J. Food Sci., 19(5), 182-188. https://doi.org/10.17221/6605-CJFS

Zieliński, H., Michalska, A., Szawara-Nowak, D., Wiczkowski, W., Piskuła, M. K. (2007). Tocotrienols in three rye varietes: from the grain to the bread. Polish J. Food Nutr. Sci., 57(4), 441-446.

Zieliński, H. (2008). Tocotrienols: distribution and sources cereals - role in human health. In R. R. Watson, V. R. Preedy (Eds.), Tocotrienols: Vitamin E beyond tocopherols (pp. 23-42). Boca Raton, FL: Taylor and Francis, AOCS. http://doi.org/10.1201/9781420080391.ch3

Žilić, S., Hadži-Tašković Šukalović, V., Dodig, D., Maksimović, V., Maksimović, M., Basić, Z. (2011). Antioxidant activity of small grain cereals caused by phenolics and lipid soluble antioxidants. J. Cereal Sci., 54(3), 417424. https://doi.org/10.1016/j.jcs.2011.08.006 